\title{
Vivir en la orfandad, pobreza y hacinamiento. Los asilos constitucionalistas y las condiciones de vida y salud de los niños en la Ciudad de México, 1915-1918
}

Living in orphanage, poverty and overcrowding. Constitutionalist asylums and the conditions of life and health of children in Mexico City, 1915-1918

América Molina del Villar

Resumen

Palabras claves

Abstract

Keywords
Centro de Investigaciones y Estudios Superiores en Antropología Social, Ciudad de México, México

Correo electrónico: avillar@ciesas.edu.mx

Licenciada en Etnohistoria por la Escuela Nacional de Antropología e Historia. Doctora en Historia por El Colegio de México (1998). Profesora-investigadora del Centro de Investigaciones y Estudios Superiores en Antropología Social. Su más reciente publicación es Guerra, tifo y cerco sanitario en la ciudad de México, 1911-1917. México: Publicaciones de la Casa Chata (2016).

Este trabajo analiza las condiciones de vida en los asilos constitucionalistas, inaugurados durante el gobierno de Venustiano Carranza. Su creación formó parte de la campaña sanitaria y de beneficencia de este personaje. Al igual que el férreo combate contra el hambre y la epidemia de tifo de 1915 y 1916, la creación de estos albergues fue ampliamente publicitada en la prensa como un gran logro del gobierno. Nuestro objetivo es presentar un panorama general sobre la situación de los asilos, su funcionamiento, población, condiciones materiales, sanitarias y algunas causas sobre su cierre en 1918.

Niños, albergues, pobreza, guerra, salud

This paper analyzes the living conditions in the constitutionalist asylums, inaugurated during the government of Venustiano Carranza. Its creation was part of the health and charity campaign of this politician. Like the fierce battle against hunger and the typhus epidemic of 1915 and 1916, the creation of these shelters was widely publicized in the press as a great achievement of the government. Our objective is to present a general panorama about the situation of the asylums, their operation, population, material, sanitary conditions and some causes about their closure in 1918.

Children, orphanage, poverty, health
Aprobado/Approved
Recibido/Received
23 de julio de 2018
9 de noviembre de 2017 


\title{
Vivir en la orfandad, pobreza y hacinamiento. Los asilos constitucionalistas y las condiciones de vida y salud de los niños en la Ciudad de México, 1915-1918
}

\author{
América Molina del Villar
}

\section{Introducción}

En 1915 la Ciudad de México lucía catastrófica, recientemente sitiada y acosada por las distintas facciones revolucionarias que se disputaron el poder desde la caída de Díaz. Desde 1911 y hasta 1917 en la capital del país y en otras zonas hubo un aumento en la incidencia de enfermedades infecciosas asociadas a la guerra, miseria e insalubridad: tifo, viruela, escarlatina y enfermedades gastrointestinales provocaron decesos en la población, particularmente en los niños. ${ }^{1}$ Los conflictos militares en el Norte, Bajío y centro del país originaron que un gran número de personas se refugiara en la Ciudad de México. Ante tanta pobreza y mendicidad, los distintos gobiernos surgidos durante los años del conflicto armado trataron en lo posible de atender la salud y bienestar de la población. ${ }^{2}$ De acuerdo con algunas opiniones, el hambre había provocado muertes, sobre todo entre los ancianos y niños que vivían en los barrios bajos, como la colonia La Bolsa, Tepito y La Viga. ${ }^{3}$

Una de las tragedias más terribles de las guerras, epidemias y hambrunas es la presencia de niños abandonados y huérfanos. Al respecto, disponemos de algunos estudios en torno a la infancia durante situaciones de conflictos armados. Cabe destacar las investigaciones y estudios de James Marten sobre la

${ }^{1}$ Sobre el impacto de la guerra y la epidemia de tifo en la Ciudad de México, véase Molina del Villar (2016).

${ }^{2}$ Ulloa (2000, p. 759-821); Azpeitia Gómez (2006).

3 Ulloa (2000, p. 161); Azpeitia Gómez (2006, p. 247-303). 
afectación a las familias, niños y jóvenes durante la era de guerras civiles en Estados Unidos y las guerras mundiales. En dichas investigaciones se pone atención en la situación de los niños huérfanos y los soldados jóvenes enviados a los frentes militares analizando diversas fuentes históricas, testimonios y cartas. ${ }^{4}$ Como señala Eugenia Meyer, en la historiografía sobre la Revolución Mexicana hasta hace unos años existía un vacío sobre el papel de la infancia, víctimas indiscutibles de la Revolución. En este sentido, señala que se requieren más análisis en torno a los efectos de la violencia en los niños, el sentido de la pérdida de los padres, las consecuencias de la migración a las grandes ciudades, la desnutrición, la salud, la mortalidad, morbilidad, abandono y falta de seguridad, fenómenos provocados por la guerra civil entre 1910 y 1920. La misma autora afirma que el estudio de la infancia durante esta guerra civil puede plantearse desde la perspectiva sincrónica y diacrónica, en la cual se analice la vida cotidiana de los niños y cómo ésta se modificó durante la lucha revolucionaria. Meyer se refiere a temas de gran interés en estos contextos de conflicto: agresiones hacia los menores, su formación moral, ética, relaciones interpersonales, la pérdida de los padres, del hogar, la destrucción de las redes sociales, el hambre, la enfermedad y la orfandad. ${ }^{5}$

La historia social, demográfica y de las mentalidades ha beneficiado el estudio de la infancia al incorporar diferentes enfoques gracias a la inclusión de diversas fuentes históricas. En relación con el tema de la niñez durante la Revolución, existen varios trabajos. Beatriz Alcubierre Moya y Tania Carreño King se adentraron en el entorno de los niños villistas, la familia, su preparación política y social. El estudio de la Revolución Mexicana presenta múltiples facetas, entre las que debe destacarse la incursión de la historia social, el ámbito de la familia, los hijos, el género y el trabajo infantil. Al respecto, hay que referir los estudios de Ann Blum, Eugenia Meyer, David Guerrero, Mario Barbosa, Susana Sosenski, entre otros. Trabajos que anteceden a este ensayo son los de

${ }^{4}$ Marten (2012). Este libro en particular incluye trece ensayos sobre los niños y la Guerra civil, en el que se analizan las imágenes y experiencias de esclavos, luchas de emancipación y conflictos armados, temas poco explorados en este tipo de estudios. Del mismo autor, véase (1998).

${ }^{5}$ Meyer (2000). 
David Guerrero y Mario Barbosa sobre la beneficencia durante la década revolucionaria. ${ }^{6}$

Desde el enfoque de la historia cultural, de las representaciones sociales y símbolos, Anayanci Fregoso estudia la infancia y maternidad en los años posrevolucionarios a través de un diario tapatío, El Informador. Para esta estudiosa revisar el papel de la prensa durante el proceso revolucionario resulta fundamental durante la reconstrucción del nuevo Estado mexicano (1917-1943), en virtud de que se presenta como una fuente productora de sentido. De ahí se explica la creciente producción historiográfica para el caso mexicano, en la cual además de los periódicos se utilizan revistas, imágenes, manuales de urbanidad, textos escolares y literarios. En su estudio, la autora encuentra que la prensa fue una de las mejores "tribunas para hacer públicas las preocupaciones sociales, políticas y económicas de los distintos actores interesados en la vida nacional". En el caso de nuestro estudio también analizamos el papel de la prensa, principalmente del periódico El Demócrata, editado en la ciudad de México porque se convirtió en el principal medio de difusión de las acciones emprendidas por Carranza, en particular de José María Rodríguez en la campaña contra el tifo, la sanidad y acciones para combatir el hambre, la mendicidad y orfandad, como fue la instalación de los puntos de socorro, comedores públicos, de la beneficencia y de los asilos constitucionalistas. ${ }^{7}$

Otro referente importante en nuestro análisis es el de Alberto del Castillo, quien se adentra también en las representaciones e imágenes de los niños en la ciudad de México durante 1880-1920. El autor analiza el papel de la fotografía en la prensa. Imágenes similares de niños desnudos, pobres y mal vestidos con otros niños, o bien ellos mismos bien vestidos y alimentados eran muy comunes en la prensa de fines del siglo XIx y principios del xx. "Estas transformaciones sintetiza el mensaje propagandístico de todo reportaje" que tenían la intención de cambiar lo atrasado y primitivo con lo moderno. Del Castillo señala que tanto en la prensa y las revistas se dedicaron amplios reportajes fotográficos a diversos

\footnotetext{
${ }^{6}$ Alcubierre Moya y Carreño King (1997); Guerrero Flores (2008, p. 61-84); Barbosa (2011, p. 186-219).

7 Fregoso Centeno (2009, p. 163-192).
} 
temas relacionados con la infancia, explorando varios aspectos como la criminología, medicina y pedagogía cívica. ${ }^{8}$

En nuestro trabajo consideramos algunas imágenes y fotografías de la prensa, principalmente en torno a las notas, artículos y entrevistas que alababan las acciones de la Beneficencia Pública para combatir el hambre y mendicidad de muchos niños en la ciudad. No obstante, nuestro ensayo da mayor peso al aspecto institucional a través del análisis de diversa documentación sobre las características y funcionamiento de los asilos, más que al tema del análisis de la imagen, discursos, símbolos y representaciones. Veremos que uno de los propósitos de los hospicios o casas de huérfanos no sólo era alimentar, cuidar y curar a los niños, sino también ofrecerles educación. ${ }^{9}$ Este último aspecto se vislumbra en los proyectos de reglamentos y oficios administrativos de los directivos de los asilos constitucionalistas hacia las autoridades de la Beneficencia Pública. El mantenimiento de estos albergues no fue fácil, pues tuvieron que afrontar problemas presupuestales, a pesar de las obras altruistas y donativos. Adentrarse en las características de estos asilos o casas de huérfanos constituye uno de los objetivos de este trabajo. Nuestra intención es mostrar su funcionamiento, así como tratar de conocer el tipo de población que albergó.

El artículo intenta responder las siguientes cuestiones. De manera similar a los hospicios y escuelas de huérfanos, los asilos constitucionalistas tuvieron un fin utilitario con el objeto de ofrecer un oficio o profesión a los niños huérfanos o pobres, cuyos padres no podían mantenerlos. La idea de educarlos se hizo con el objeto de contrarrestar la vagancia en la ciudad, sobre todo en estas circunstancias generadas por la Revolución. La documentación disponible permite observar que no sólo fueron albergues temporales, sino que hubo esfuerzos de elaborar proyectos de reglamento que regularan las actividades a su interior, la alimentación, la disciplina, las condiciones sanitarias, así como la función y tareas de cada uno de los empleados de los asilos. La segunda cuestión tiene que ver con las fuentes de financiamiento en una coyuntura de

\footnotetext{
8 Del Castillo (2009).

9 Sobre estas campañas de educación e higiene, véase el libro colectivo de Agostoni (2008). En relación al papel del Estado en la Beneficencia en el periodo anterior a nuestro estudio, véase Lorenzo Río (2011, p. 30, 31).
} 
cambios en la Beneficencia impulsado por el gobierno de Carranza. Exploraremos las posibles repercusiones de la supresión de la Lotería Nacional en el monto destinado a las instituciones de Beneficencia, tema que ofrece diversas vertientes para investigaciones futuras. El tercer tema es contrastar la difusión propagandista de la prensa simpatizante del proyecto de Carranza con la realidad al interior de los asilos, en donde de acuerdo con las visitas e inspecciones médicas algunos de ellos carecieron de condiciones sanitarias adecuadas y, en consecuencia, hubo una proliferación de enfermedades infecciosas. Podemos ver gracias a las estadísticas de ingresos de niños y del personal que las instituciones de la Beneficencia no se dieron abasto para afrontar la pobreza y mendicidad imperante.

El material empírico que sustenta el estudio son las notas e imágenes de la prensa, así como documentación de archivo de carácter oficial y administrativo de los ramos Beneficencia, Asilos Constitucionalistas y Dirección General resguardad en el Archivo Histórico de la Secretaría de Salubridad y Asistencia (en adelante, AHSSA). Los asilos constitucionalistas, hospicios y hospitales dependían de la Dirección General de la Beneficencia y ésta a su vez de la Secretaría de Gobernación. Fue a través de este ramo por donde se ventilaban los problemas de índole administrativo y presupuestal. De ahí derivó una gran cantidad de documentación de diversa naturaleza: oficios, informes, visitas, protocolos, proyectos de reglamentos, inspecciones, presupuestos, fichas de control y abasto de alimentos, bienes y ropas, cuadros y estadísticas de ingresos de asilados, del personal y familiares que vivían en los establecimientos asistenciales. La compra de alimentos, bienes y todo tipo de aprovisionamiento a los asilos se hacía a través de la Proveeduría, instancia que era dirigida por el director de la Beneficencia, quien desde 1877 autorizaba todas las compras. ${ }^{10}$ Este material ha sido muy útil para conocer el funcionamiento interno, quejas contra directores y administrativos, solicitud de apoyo económico y problemas presupuestales de los establecimientos asistenciales y de los mismos asilos constitucionalistas. ${ }^{11}$

\footnotetext{
${ }^{10}$ Lorenzo Río (2011a, p. 93).

${ }^{11}$ Este gran fondo documental se encuentra en: AHSSA, Beneficencia Pública, Dirección, Dirección General, legs. 18, 19, 20, 23, 25, 26.
} 
Esta información podemos contrastarla con las notas de la prensa, la cual se consagró a alabar las óptimas condiciones de los asilos y la gran obra benéfica para combatir la mendicidad. Fotograbados con los niños limpios y sanos, imágenes del presidente y su esposa visitando estos albergues pueden confrontarse con el sinnúmero de oficios, cartas, quejas, estadísticas, documentos que permiten observar que dichos lugares atravesaron por situaciones complicadas, debidas en gran medida a la falta de personal, la gran cantidad de niños asilados y presupuestos limitados.

El texto se divide en tres secciones. Primero, presentaremos un panorama histórico de la situación general de la ciudad de México entre 1915 y 1916, en particular mencionaremos algunos rasgos de los hospicios de niños, como la Casa de Niños Expósitos y el Hospicio de Pobres. En el segundo apartado analizaremos algunos proyectos de reglamentos de algunos asilos, en los que podemos apreciar su función y objetivo. En la tercera sección nos adentraremos en las características físicas de los asilos constitucionalistas, su ubicación, infraestructura, condiciones sanitarias, al igual que referiremos algunas enfermedades reportadas en los registros médicos. En las reflexiones finales repararemos en algunas causas de su clausura definitiva en 1918.

\section{Los establecimientos asistenciales en la Ciudad de México}

La guerra, hambre y pobreza convirtieron a la capital del país en un lugar insalubre. No sólo el tifo provocó un gran número de decesos, sino también enfermedades gastrointestinales originadas por la mala calidad de agua, basura y drenaje nauseabundo. Las enfermedades respiratorias y gastrointestinales fueron la principal causa de muerte, sobre todo entre los grupos de cero a cuatro años y de cinco a nueve años. ${ }^{12}$ La elevada mortalidad infantil fue motivo de gran preocupación de los gobiernos posrevolucionarios; ésta se agudizó en los años de la Revolución. Durante la fase del conflicto armado murieron muchos individuos a consecuencia de la guerra y de las enfermedades infecciosas. La

12 Molina del Villar (2016, p. 242). La mortalidad infantil (MI) es la que ocurre antes del primer año de vida, la cual puede ser un indicador importante del nivel de desarrollo de un país. Hernández Bringas (2001, p. 37, 38). 
desorganización administrativa provocada por la crisis política y social en la ciudad de México no permite llegar a cálculos exactos en torno al número de habitantes, niños huérfanos y pobres que deambulaban en las calles de la capital, tema que era aludido constantemente en la prensa durante estos años. Al respecto, Ordorica y Lezama se cuestionan hasta qué punto la Revolución provocó una redistribución de la población. ¿Es posible identificar cambios en los patrones de natalidad, mortalidad y migración entre 1910 y 1921? La respuesta a esta cuestión se ve obstaculizada por las deficiencias de las estadísticas, especialmente vacíos de información y falta de datos precisos que podemos extraer al comparar los dos únicos censos disponibles para esos años: el de 1910 y 1921. Tanto un censo como el otro adolecen de diversas dificultades técnicas y metodológicas. El último, por ejemplo, se vio afectado en su organización, fecha de verificación y cobertura. La falta de cooperación, el cambio de autoridades, las numerosas y ambiguas instrucciones y la falta de preparación del personal hacen dudar acerca de la veracidad de estas fuentes. Diversos autores han señalado las serias dificultades de analizar ambos censos. ${ }^{13}$

No obstante, sabemos que uno de los cambios demográficos más importantes durante la Revolución fue la disminución de los niños menores de diez años. En 1910 la población de este grupo era de 4.8 millones frente a 3.1 millones en 1921. Esta disminución puede atribuirse a problemas de subregistro, así como a una disminución de la natalidad. Hay que referir a la elevada mortalidad infantil a consecuencia de las enfermedades gastrointestinales y respiratorias, así como la incorporación de población joven a la guerra. Desde 1910 diversos niños entre diez y quince años ingresaron a las filas militares. La población rural fue más afectada que la urbana. Durante estos años hubo una fuerte migración a la capital del país, por lo que a pesar de la guerra y enfermedades ocurrió un crecimiento del uno por ciento durante 1910 y $1921 .{ }^{14}$ En 1910 había en el Distrito Federal 720753 habitantes, de los cuales 148602 eran niños menores de diez años, es decir el 20.6\%.15 En 1921 había 906063 habitantes en el Distrito

${ }^{13}$ Greer Gordon (1966); González Navarro (1974).

${ }^{14}$ Ordorika y Lezama (1993, p. 41-44).

${ }^{15}$ Censo de Población de Estados Unidos Mexicanos, t. 1, México, Oficina Impresora de la Secretaría de Hacienda, 1918. 
Federal, en tanto 189834 eran menores de diez años, es decir el 20.9\%. ${ }^{16}$ Así, en el caso de la capital del país observamos un crecimiento de los niños en esos rangos de edad, debido quizá a la migración de las familias que huyeron del conflicto armado, aunque en términos porcentuales no hubo gran diferencia de la población infantil entre 1910 y 1921.

Al iniciar el siglo xx se percibe un gran interés en la figura del niño. Médicos, higienistas, literatos y periodistas señalaban en muchos tipos de publicaciones periódicas toda clase de recomendaciones sobre la crianza, cuidado y la correcta formación de los niños, la alimentación, los sentimientos, la formación de los valores. La Revolución trastocó estos aspectos, por lo que hubo una seria preocupación por parte de los gobiernos posrevolucionarios. ${ }^{17}$ En los años $20 \mathrm{y}$ 40 del siglo pasado se llevaron a cabo programas de educación, higiene y mejoramiento de la salud de los niños. ${ }^{18}$ Las acciones de Carranza en la creación de estos asilos constitucionalista revela su interés en atender la beneficencia pública, en el marco de su campaña quizá para afianzarse y legitimarse en el poder después de la cruenta lucha entra las distintas facciones revolucionarias.

En relación con la función que cumplían estos asilos y las diversas casas de la Beneficencia es necesario referir a algunas concepciones de mediados del siglo xIx en torno a los pobres y la vagancia. Durante los años de 1915 y 1918 proliferaron en las calles de la ciudad un gran número de indigentes, principalmente niños, muchos de los cuales fueron considerados en la prensa como "futuros delincuentes". ${ }^{19}$ David Guerrero señala que en aquellos años entre julio y diciembre de 1918 fueron consignados 232 boleros, 165 en julio, 50 en agosto y septiembre, y 17 en octubre. El administrador general de Rastros y Mercados señaló que bajo este oficio estos niños boleros cometían "abusos y raterías" sin que en realidad fueran boleros. Para evitar la reclusión se debía pagar una multa

${ }^{16}$ Esta cifra es extraída a partir de la resta del total de habitantes en el Distrito Federal (906 063) del total de población de diez años en adelante (716 229). Censo General de Habitantes 1921, Instituto Nacional de Estadísticas. (www.inegi.org.mx) Fecha de consulta 30 de mayo de 2018.

${ }_{17}$ Guerrero Flores (2007, p. 121-147).

18 Sobre estas políticas y programas gubernamentales de protección a la infancia en el periodo posrevolucionario, véase el espléndido estudio de Alanís (2016, p. 20-26, 175-240).

19 El Demócrata, 22 de marzo de 1916, p. 2. 
o licencia, dinero que muy pocos disponían. ${ }^{20}$ Desde el siglo xIX prevalecían concepciones en torno a considerar a los pobres como "ociosos" y "un lastre". $\mathrm{Al}$ respecto, Dolores Lorenzo señala de qué manera la vinculación del crimen con los pobres fue una concepción común entre diversos grupos de la élite del siglo xIx. La autora se refiere a la literatura en la cual se vincula la pobreza con el delito, cuya base ideológica se remitía al control o a la segregación de quienes representaban un peligro para la sociedad y el Estado. Para erradicar este mal los sistemas asistenciales impulsaron la creación de talleres de oficios en los establecimientos asistenciales. ${ }^{21}$

Bajo concepciones positivistas y darwinianas, en la segunda mitad del siglo XIX se fue conformando una multiplicidad de ideas en torno a los pobres e iniciativas para atender sus necesidades. Al interior de este conglomerado de ideas se observan planteamientos del utilitarismo presente en los discursos de auxilio al necesitado, dando gran peso al Estado, que se convirtió en el principal actor de La Beneficencia. La idea y principal responsabilidad del Estado era "hacer algo útil para los pobres" que habían aumentado de manera vertiginosa en los barrios más paupérrimos de la ciudad, en donde se reproducían todos los problemas sociales como la mendicidad y el crimen, de acuerdo con las consideraciones de las élites. ${ }^{22}$

La Beneficencia Pública era la responsable del funcionamiento de la Casa de Niños Expósitos, la Escuela Industrial de Huérfanos, el Hospicio de Pobres, los hospitales (Castañeda, Hospital General y Hospital Juárez), al igual que los establecimientos creados exprofeso para combatir el hambre y la mendicidad, como fue el caso de los comedores públicos, puestos de socorros, dormitorios y los asilos constitucionales. Para conocer las características de estos establecimientos debemos referir a las acciones emprendidas por Porfirio Díaz. En 1877 se creó la Dirección General de Beneficencia Pública, cuyo objetivo era regular las instituciones de asistencia en la capital a través de la Secretaría de Gobernación. Desde entonces este organismo ya no dependería de las corporaciones municipales; éstas dejaron de tener el control directo de los

\footnotetext{
${ }^{20}$ Guerrero Flores (2007, p. 140, 141).

${ }^{21}$ Lorenzo Río (2011, p. 30, 31).

22 Lorenzo Río (2011a, p. 37-38).
} 
establecimientos de socorro público. La idea de centralizar y separar la Beneficencia de la corporación municipal era con el objeto de combatir la corrupción a partir de una administración más eficiente. Como ha estudiado Lorenzo, otro mecanismo importante fueron las operaciones de la Lotería Nacional, promovida por el médico Eduardo Liceaga en ese mismo año, que dependería de la Secretaría de Gobernación. ${ }^{23}$ Así, el gobierno federal se adjudicó, además de todos los recursos materiales de la Beneficencia, una importante fuente de poder, influencias y legitimidad. ${ }^{24}$

Como se dijo al principio, fue a través de la Dirección General del ramo de la Beneficencia por donde se ventilaban los problemas de índole administrativo y presupuestal. De ahí derivó una gran cantidad de documentación de diversa naturaleza y qué analizaremos en este trabajo para adentrarnos en las características y función de los asilos constitucionalistas. De manera particular debemos referir un informe de 1923, el cual a pesar de ser posterior a la fecha de estudio del trabajo permite conocer la organización de la Beneficencia Pública en los años del gobierno de Carranza y que constatamos al revisar la documentación. La Dirección General estaba encargada del suministro de los alimentos, muebles, vestuarios y artículos alimenticios a los establecimientos asistenciales. La Beneficencia disponía además de una administración de Bienes Propios destinada al manejo de los capitales, legados y donativos. La Dirección General se encontraba dividida en una secretaría general y mesas de personal, estadísticas, asilados, pedidos, contabilidad y glosa, archivo y oficialía de partes y consagradas. ${ }^{25}$

Durante los años del conflicto armado también tuvieron un papel importante el Hospicio de Pobres (1774) y el Tecpam de Santiago (la Escuela Industrial de Huérfanos), en los cuales también se recluyeron niños huérfanos. En relación con el primer establecimiento, Arrom se refiere que en 1871 el Hospicio empezó a cambiar y a tener un carácter humanitario de "disciplinar a los pobres",

23 Lorenzo Río (2011a, p. 94); Lorenzo Río (2011b, p. 112-147).

24 Rodríguez Kuri (1996, p. 57-59).

25 “Informe del Director General de la Beneficencia del Distrito Federal al Boletín de la Confederación de la H. Cámara de Comercio. 1923”. AHSSA, Dirección. Dirección General, leg. 21 , exp. 23 , f. 49. 
características que también observamos en los reglamentos de los asilos constitucionalistas y en otros establecimientos asistenciales. El rasgo coercitivo del Hospicio de Pobres se modificó, en virtud de que el inmueble se redujo y a mediados del siglo XIX se transformó en un internado de niños huérfanos. ${ }^{26}$ Por su parte, el Tecpam de Santiago, denominado en el Porfiriato Escuela Industrial de Huérfanos, estudiado por Dolores Lorenzo, fue fundado en 1841 y se encontraba en la periferia, en un barrio indígena de la parcialidad de Santiago. Esta escuela representaba muy bien estas concepciones utilitarias en torno a la función que debían tener las instituciones de beneficencia de combatir la mendicidad y la posible delincuencia. La Escuela se concibió como un "monumento a la forma de educar al pueblo", consistiendo en alternar el trabajo manual y la enseñanza escolar, un altar al trabajo en el taller". ${ }^{27}$

En un principio la función del Tecpam de Santiago era recluir a los menores infractores y comenzar su corrección. No obstante, existía la necesidad de amparar a los huérfanos de las clases pobres, quienes carecían de padres o bien eran abandonados por los "vicios" de sus progenitores. De este modo, en el colegio convivían niños infractores con niños pobres considerados honrados. En el Porfiriato hubo ciertas reformas y modificaciones para trasladar a los niños delincuentes a una nueva correccional establecida en el pueblo de Coyoacán. ${ }^{28}$ De la documentación disponible se desprende que en los cinco asilos constitucionalistas no solo se alojaron huérfanos, sino también familias, ancianos y otros niños cuyos padres estaban incapacitados para alimentarlos. Nos interesa mostrar que estos albergues temporales fueron insuficientes para atender a una creciente población en pobreza, pues se comprueba que muchos de ellos no solo albergaron niños, sino también familiares del personal que laboraba en estos establecimientos. Los recursos fueron cada vez más limitados, mostrando signos de inoperancia desde antes de la caída de Carranza al frente del gobierno. En un periodo de crisis y pobreza generalizada, como la que se experimentó en 1915 y 1916, encontramos que en los asilos no solo había niños huérfanos, sino también algunos tenían a uno de sus padres, quienes no disponían de los medios

\footnotetext{
${ }^{26}$ Arrom (2011, p. 17-32).

27 Lorenzo Río (2011a, p. 40).

${ }^{28}$ Lorenzo Río (2011a, p. 70-77).
} 
para mantenerlos. $\mathrm{Al}$ respecto, Dolores Lorenzo refiere a las redes de parentesco y clientelares al interior en el Tecpam de Santiago. Muchos familiares de los empleados y de la propia directora se incorporaban a las tareas cotidianas del establecimiento. ${ }^{29}$ En algunos asilos constitucionalistas residían uno o dos familiares de la directora, administradora, portero, criada, enfermera, lavandera, mozo, vigilante, enfermera y cocinera. ${ }^{30}$

Del tipo de población asiladas en estos establecimientos los reglamentos de Beneficencia Pública de fines del siglo xix señalaban que la Escuela Industrial de Huérfanos admitirían sólo a varones indigentes entre diez y catorce años, en tanto en el Hospicio de Pobres se alojarían ancianos desvalidos de ambos sexos y niños mayores de siete años y menores de diez, así como a niñas mayores de siete y menores de catorce. ${ }^{31}$ En 1915 en los asilos constitucionalistas se internaron niños indigentes, cuyas edades coinciden con la de los internos del Hospicio de Pobres y de la Escuela Industrial de Huérfanos. El egreso de los niños a la edad de catorce años podría ser un indicio de que se incorporaban al mundo laboral después de recibir cierta instrucción. Como señalan Guerrero y Sosenski, las fronteras entre la infancia, la adolescencia, la juventud y la vida adulta no estaban del todo delimitadas. En este caso muchos de los niños comenzaban a trabajar a muy temprana edad. Los oficios eran variados: barridos de calles, atizar hornos de barbacoa, cuidado de caballos, mensajeros, lavaplatos, entre otros. Sin duda, la pobreza y orfandad eran los principales motivos del trabajo infantil. ${ }^{32}$ Los asilos constitucionalistas no sólo tuvieron la función momentánea de albergar a enfermos, ancianos y huérfanos con el objeto de alimentarlos, sino que igual que el Hospicio de Pobres y la Escuela Industrial de Huérfanos, la idea era que aprendieran un oficio e instruirles rutinas de higiene.

29 Lorenzo Río (2011a, p. 107).

30 "Lista duplicada de los empleados que viven con su familia en los diversos establecimientos dependientes de la beneficencia pública, para descontarles su sueldo un peso diario por persona. 1916" AHSSA, Beneficencia Pública, Dirección, Dirección General, leg. 21, exp. 12, f. 17 .

${ }^{31}$ Lorenzo Río (2012); Lorenzo Río (2011a). Durante el Porfiriato el Hospicio para Niños, el Manicomio General de la Castañeda y el Hospital General recibieron recursos de la Lotería, lo que permitió su modernización. Estas instituciones también recibieron recursos del Ayuntamiento.

32 Guerrero Flores (2007, p. 121-138); Sosenski (2010, p. 21). 
La salud y cuidado infantil se convirtieron en temas de alta prioridad en el gobierno. Al interior del régimen surgido de la Revolución se dio gran importancia a la "educación higiénica”, en la que el Departamento de Salubridad Pública y la Secretaría de Educación Pública formaron áreas especializadas en educación e higiene, aspecto relacionado con la atención a la infancia. En este sentido, Aréchiga se refiere al término de "dictadura sanitaria", en el cual el Estado tenía el derecho de intervenir sobre la higiene del individuo, particular y colectivamente. La higiene escolar fue la punta de lanza para inspeccionar escuelas, su buen funcionamiento, distribución adecuada de los salones y provisión de baños adecuados para niños y niñas. ${ }^{33}$

Impartir educación a los indigentes fue un tema enarbolado por las élites de la capital, por lo que los establecimientos de asistencia debían cumplir múltiples funciones de brindar un oficio, de educación y de impulsar hábitos de higiene. ${ }^{34}$ En este ensayo comprobamos estas ideas en torno a la higiene y educación al analizar los proyectos de reglamentos de los asilos constitucionalistas, pues encontramos artículos sobre disciplina en el cuidado y limpieza que debían procurar los niños; por ejemplo, horarios de comida, baño y cambio de ropa. Cabe señalar que a principios del siglo xx el trabajo infantil era aceptado y se consideraba normal. En su estudio sobre el trabajo infantil en la ciudad de México, Susana Sosenski se refiere a diversos proyectos gubernamentales que se encargaron de promocionar el trabajo en las instituciones educativas y correccionales. En este sentido, la prensa publicaba ofertas laborales para niños, las mujeres acudían a los orfanatos a solicitar niñas como sirvientas, o bien se aceptaba que los niños de nueve a diez años podían emplearse en las fábricas. ${ }^{35}$ Más adelante veremos que los asilos constitucionalistas contaban con talleres

33 “El 18 de enero de 1917 el Congreso Constituyente reunido en Querétaro dedicó parte del día a la discusión de los artículos que debían regir la creación y regulación de las instituciones de salubridad pública de la nación. José María Rodríguez, presidente del Consejo Superior de Salubridad, pronunció un discurso que sentaría las bases para el artículo 73 constitucional. Para Rodríguez debía conformarse un Departamento de Salubridad General de la República, el cual dependería del ejecutivo y cuyas disposiciones debían ser atacadas por los gobiernos de los estados". Aréchiga Córdoba (2007, p. 73, 74). Sobre los servicios de higiene escolar, véanse los estudios de Carrillo (1999, p. 71-74); Carrillo (2005, p. 145-178).

34 Lorenzo Río (2011a, p. 77-88).

35 Sosenski (2010). 
de instrucción para la enseñanza de diversos oficios: herreros, ebanistas, relojeros para los hombres, mientras a las mujeres se les instruía en labores del hogar y si tenían "mejor aptitud" enseñarles mecanografía, taquigrafía y "hasta inglés".

Cabe señalar que entre los establecimientos que ocupaban menores de edad había talleres de costura, fábricas de hilados y tejidos, de calzado, de puros y cigarros, muñecas, lavanderías, ebanistería, talabartería y herrería. ${ }^{6}$ De ahí la necesidad de que los niños aprendieran un oficio en estos asilos para poder ser empleados en los talleres y fábricas. Hay que recordar que la edad máxima para permanecer en el asilo era de catorce años, edad a la que se incorporaban al taller o a la fábrica. Los artículos 3 y 123 de la Constitución Política de 1917 restringieron el trabajo de los niños, lo que representó un avance en la protección educativa y laboral de los menores de edad. Empero, esta legislación no tuvo una aplicación inmediata, ya que como analiza Sosenski los niños continuaron trabajando en fábricas, talleres, espacios callejeros y en el servicio doméstico entre 1920 y 1934. No obstante, Blum señala que desde principios del siglo xx con la consolidación de una clase media y alta, se consideró que los niños debían tener la oportunidad para jugar y tener tiempo libre. ${ }^{37}$

\section{Los cinco asilos para combatir la mendicidad, los vagos y "pequeños infractores"}

A principios de agosto de 1915 las fuerzas carrancistas recuperaron la capital del país y desalojaron a los zapatistas de los puntos estratégicos del Distrito Federal. Las primeras acciones del gobierno se centraron en combatir la epidemia de tifo y sanidad de la ciudad. La desorganización política y administrativa era evidente y había una falta de recursos. La llegada de Carranza implicó cambios en el funcionamiento del gobierno municipal y del Gobierno del Distrito

${ }^{36}$ Guerrero Flores (2007, p. 144). Sosenski (2010, p. 89-142).

37 Lorenzo Río (2011a, p. 15). A partir de 1906 con la consolidación de una clase media y alta, se consideró que los niños debían tener la oportunidad para jugary tener tiempo libre -que era la antítesis del trabajo-, así como a la educación. También se asiste a una nueva concepción en torno a la división de género en cuanto al cuidado de los padres, siendo las mujeres las responsables de cuidar a los niños en el mismo hogar. Blum (2009, p. XVIII). 
Federal, principalmente a través de la derogación y restablecimiento de la Ley de 1903 sobre Organización Política del Distrito Federal. Dicha ley suprimía la personalidad jurídica de los ayuntamientos, instancias a las que se les despojó de sus bienes inmuebles que pasaron a la jurisdicción del gobierno nacional. A los ayuntamientos se les impidió cobrar impuestos, rentas y derechos, convirtiéndose en órganos consultivos de un Ejecutivo colegiado que dependía directamente del presidente de la república. Carranza derogó esta ley y restituyó la autonomía a varios municipios: Guadalupe, Hidalgo, Azcapotzalco, Xochimilco, Tulyehualco, Tlahuac, San Pedro Actopan, Tlalpan, Coyoacán, entre otros. A partir de entonces los ayuntamientos volvieron a tener control sobre sus bienes raíces, acciones, rentas y puestos que detentaban antes de 1903. Otro giro ocurrió cuando se afianzó el triunfo de los constitucionalistas sobre los villistas y zapatistas. Fue entonces cuando el Primer Jefe suprimió la autonomía del gobierno municipal de la ciudad de México y sustrajo oficinas y rentas del ayuntamiento, es decir volvió a restablecer y puso en vigor la Ley de $1903 \cdot{ }^{38}$

Este cambio es importante señalarlo con respecto a la Beneficencia de la que dependían los establecimientos asistenciales, como los hospicios y asilos constitucionalistas. A reserva de hacer una investigación más detallada, planteamos como hipótesis que los recursos para la beneficencia derivaron de la hipoteca y remate de bienes municipales, en virtud de que los donativos particulares y aportaciones de algunas secretarías no eran suficientes. De este modo, como había prevalecido hasta entonces los recursos públicos (federales y municipales) fueron el medio principal de manutención de la beneficencia pública, aunque también hubo donativos privados. Al respecto, es importante referir el señalamiento de Dolores Lorenzo de analizar los vínculos entre la beneficencia privada y pública, aspecto que constituye un tema a explorar en la historiografía de la asistencia en México. ${ }^{39}$

Otra medida que también afectó a la Beneficencia fue que el gobierno de Carranza suprimió la Lotería Nacional, importante fuente de financiamiento. De acuerdo con el Primer Jefe Constitucionalista, "no se podía continuar financiando la asistencia pública con dineros provenientes del juego y azar, una

\footnotetext{
${ }^{38}$ Rodríguez Kuri (2010, p. 115, 116).

39 Lorenzo Río (2011a, p. 43, 44).
} 
actividad considerada inmoral". La Beneficencia Pública fue refundada y recibió presupuesto federal además de los fondos de las rentas e hipotecas de sus propiedades..$^{40} \mathrm{Al}$ respecto, disponemos de algunas evidencias históricas en torno a las fuentes de financiamiento para sufragar los gastos de los establecimientos asistenciales. En 1917 a la Beneficencia Pública se donaron diversos productos: carne, dulces, ropa, libros, medicinas y muebles, los cuales fueron recibidos por la Inspección General de Policía y repartidos al Hospicio de Niños, Escuela Industrial de Huérfanos y a dos asilos constitucionalistas. En febrero de ese año la Comisión del Partido Liberal Constitucionalista, presidido por el señor Antonio Prieto, entregó en el Palacio Nacional 2837 bolsas de dulces para ser distribuirlos entre los "niños asilados en los diferentes establecimientos de esta institución". ${ }^{41}$

La ropa, calzado y otros bienes también podían llegar a través de donativos de instancias de gobierno, como la Secretaría de Guerra. En marzo de 1917, el director general de la Beneficencia Pública, el doctor Lorenzo Sepúlveda, giró una orden para que se presentaran el domingo a Tacubaya 500 niños del Hospicio y 500 de la Escuela Industrial de Huérfanos; 500 niñas del Hospicio y 250 niñas de los asilos número 2 y 3, a quienes se les repartió ropa, calzado y hojalatería. Las niñas del asilo constitucionalista número 2 recibieron 2,250 falditas de tela Vichy y 238 sombreros, mientras a las niñas del asilo número 3 se les repartió 259 pares de zapatos, 182 faldas de cambaya y 240 sombreros. Entre los donativos hechos por diferentes organismos se señala los establecimientos fabriles militares de San Diego, que enviaron prendas de vestuario y calzado. ${ }^{42}$

Otra fuente de recursos fue a través del remate de lotes municipales. A fines de 1917 el doctor Lorenzo Sepúlveda informó al proveedor general de la Beneficencia de la autorización del presidente municipal para el remate de 62 lotes

40 Barbosa (2011, p. 186-219).

41 "Donativos hechos a la institución y repartidos a los centros de Beneficencia. 1917"; Carta del director general y enviada al c. director de los establecimientos fabriles del ejército constitucionalista. 31 de marzo de 1917, f. 31. AHSSA, Dirección, Dirección General, leg. 22, exp. 7, 1917, f. 49.

42 "Carta del director general de la Beneficencia Pública al subsecretario de Gobernación, Manuel Aguirre Berlanga. 17 de marzo de 1917”. AHSSA, Dirección, Dirección General, leg. 22, exp. 7,1917 , f. 15 . 
de los "bienes declarados mostrencos". La mitad de esta venta se destinaría “para el alivio de los menesterosos". Finalmente se logaron obtener \$208.48 para la Beneficencia Pública. ${ }^{43}$ Entre 1916 y 1918 al doctor Lorenzo Sepúlveda llegaron números oficios, informes, solicitudes y cartas en torno a la situación de los establecimientos asistenciales, como la de los hospicios y asilos constitucionalistas.

La Beneficencia Pública dependía directamente de la Secretaría de Gobernación y durante la gestión de Carranza observamos una mayor centralización en el manejo de la asistencia y sanidad. El general puso a militares de su confianza en la presidencia y secretaría del cabildo. ${ }^{44}$ Por ejemplo, en febrero de 1916 Pablo González, jefe del Ejército del Oriente y responsable de sitiar militarmente la ciudad, envió una carta al doctor Sepúlveda informando que en el asilo diurno se carecía de alimentos para atender a 150 asiladas, en particular solicitaba harina, maíz y frijol a precios moderados. ${ }^{45}$

En agosto de 1915 Carranza fundó un asilo para los niños huérfanos y las viudas de los soldados muertos en campaña. Este albergue se estableció en el Antiguo Colegio de Mascarones, en Tacuba. En octubre de dicho año, la Beneficencia Pública se encargó de velar por el cuidado de "un gran número de niños que se encontraban vagando por las calles". Para entonces ya funcionaban tres asilos de menores: la Casa de Cuna Constitucionalista que albergaba a 550 niños, el Asilo Constitucionalista para niños que brindaba socorro a 400 menores y daba alimento a 200 madres, y el Asilo Constitucionalista para Niñas que atendía a 300 huérfanas. ${ }^{46}$

El promedio mensual de niños que ingresaban a los asilos constitucionalistas fluctuaba entre 200 y 400. En marzo de 1916 la Dirección General de Beneficencia elaboró un cuadro general del movimiento anual y mensual de niños que fueron enviados a la Escuela Industrial de Huérfanos, Hospicio de

43 “Carta enviada al C. Miguel Cantú Cárdenas, proveedor general de la Beneficencia Pública del DF, escrita por el director general y fechada el 4 de diciembre de 1917”. AHSSA, Dirección. Dirección General, leg. 22, exp. 7. f. 49.

44 Barbosa (2012, p. 363-408).

45 “Correspondencia particular del general Pablo González”. AHSSA, Beneficencia Pública, Dirección, Dirección General, leg. 20, exp. 12, 24 f.

46 Azpeitia Gómez (2006, p. 300). 
Niños, Casa de Niños Expósitos y los cuatros asilos constitucionalistas. En la siguiente gráfica simplificamos dicha información. No disponemos de información del año de 1917, pero podemos apreciar que el número de ingresos se mantuvo más o menos constante entre 1916 y 1918, años críticos debido a la pobreza imperante y diseminación de enfermedades infecciosas en la ciudad de México. El Hospicio de Niños fue el que hospedó el mayor número de niños. Los asilos constitucionalistas mantuvieron casi el mismo número de ingresos. En abril de 1916 la directora del asilo número 1, Antonia Landgrave viuda de Flores manifestó que el número de asilados ascendía a la cantidad de 405 personas, la mayor parte niños de ocho, diez, doce y catorce años. ${ }^{47}$

El primer asilo constitucionalista estaba en la calle Puente de Alvarado. El número 2 en la quinta calle de Donceles número 121; el número 3 en la Plaza de la Merced; el cuarto destinado para ancianos se ubicaba en Popotla, en la calle de Árboles, número 26; el número 5 "para hijos constitucionalistas exclusivamente", en la calle de Héroes, número $44 \cdot{ }^{48}$ Los asilos o albergues creados por el régimen de Carranza fueron principalmente estancias temporales para acoger a un gran número de niños. En un principio la idea era dar cobijo a los huérfanos de la guerra, principalmente a los hijos de militares y hombres que lucharon y perdieron la vida en el campo de batalla. Así, en el asilo constitucionalista número 4 de Popotla el jefe del Departamento de la Secretaría de Marina envió un oficio al Secretario de Gobernación solicitando que se diera asilo a los niños María Luisa Ruíz, Abelardo Castañeda, Guadalupe y Miguel Méndez, cuyos padres habían muerto en campaña, "luchando por la causa constitucionalista”. A las viudas no les alcanzaba con la pensión concedida "para el mantenimiento de sus hijos". Los huérfanos fueron ingresados en los asilos número 4 y 3 . Al parecer en el segundo se internaron a los varones, mientras las niñas

47 “Informe de Amparo R. de Cárdenas, 15 de abril de 1916. El oficio se envía al director de la Beneficencia Pública”. AHSSA. Dirección. Dirección General, leg. 18, exp. 21.

48 "Lista de los establecimientos dependientes de la Beneficencia Pública. 1916. Oficio suscrito por el sr. Sepúlveda de fecha 7 de marzo de 1916 y remitida al lic, Don Jesús Acuña, secretario de Gobernación, Querétaro". AHSSA, Beneficencia Pública, Dirección, Dirección General, leg. 20, exp. 17, $5 \mathrm{f}$. 


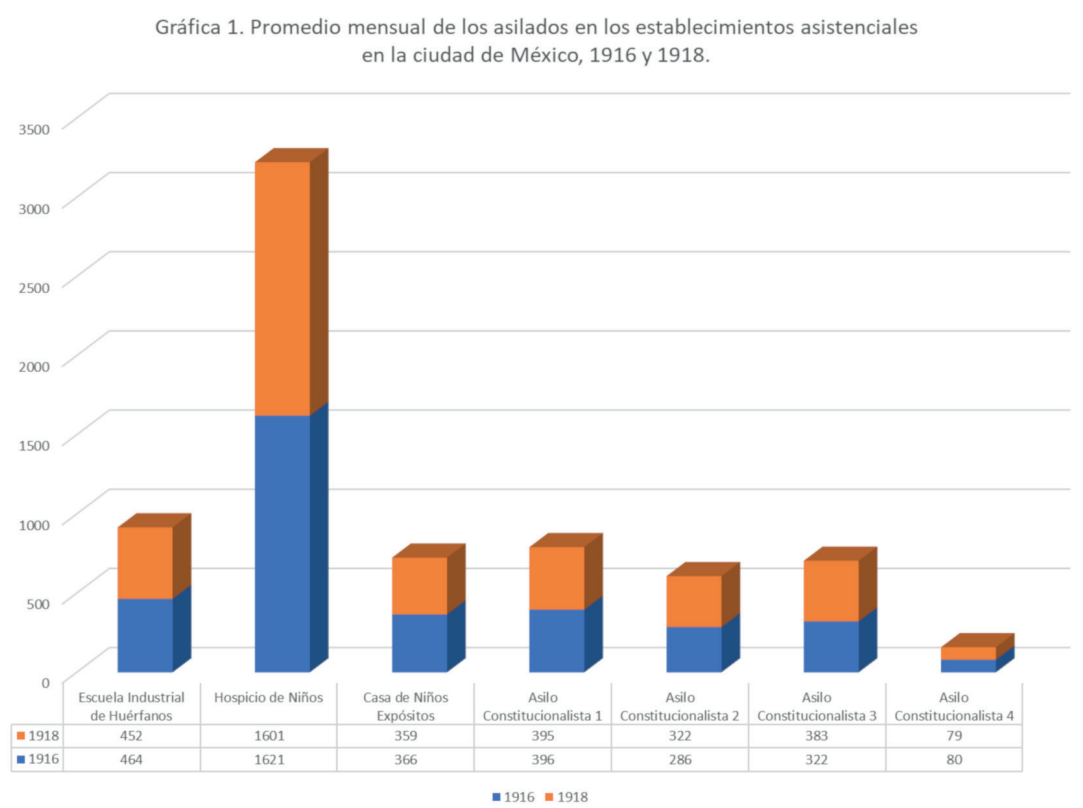

Elaboración propia con base en: Asilados. "Movimientos de los asilados en los establecimientos de la beneficencia. 1916." AHSSA, Dirección. Dirección General, leg. 20, exp. 9.

fueron llevadas al asilo 4 de Popotla que en un principio estaba destinado a los ancianos. ${ }^{49}$

A partir de 1916 hubo diversos encuentros académicos de especialistas sobre el desarrollo de los niños, la medicina y pedagogía, que combinados formarían un nuevo campo denominado puericultura, la cual conjuntaba salud infantil con el ambiente familiar y social..$^{\circ}$ Adentrarse en las características de estos asilos o casas de niños temporales permite conocer los primeros indicios de estas iniciativas, las cuales se plasmaron en la Constitución de 1917. Sin embargo, como veremos a lo largo de este trabajo, estos asilos o casas de

49 "Carta del despacho de Marina al Secretario de Gobernación sobre el ingreso de niños huérfanos por la lucha constitucionalista. Ciudad de México, 11 de agosto de 1916”. AHSSA, Beneficencia Pública. Establecimientos asistenciales. Asilos Constitucionalistas, leg. 10, exp 3 , f. 1-7.

${ }^{50}$ Blum (2009); Alanis (2016). 
huérfanos padecieron de muchos problemas sanitarios y presupuestales, fenómeno que se explica en gran medida por un periodo inestable y todavía violento.

Una preocupación de los directivos de los asilos constitucionalista fue precisamente la estrecha convivencia de niños con adultos y ancianos. En estos años aciagos la pobreza llegó a tal grado que en la ciudad había un gran número de niños y ancianos en situaciones de abandono. El asilo constitucionalista número 4 albergó población adulta, la cual fue registrada en "dos listas de ancianos": nueve hombres y quince mujeres mayores de 60 años, tres de ellas registradas como paralíticas, las cuales se encontraban incapacitadas para bastarse por sí solas; las mujeres se contabilizaron en una lista denominada de ancianas, cuyas edades estaban por debajo de 60 años; muchas de ellas mujeres que en la época actual podemos considerar jóvenes de 30 a 57 años. ${ }^{11}$

El gobierno carrancista fundó varios comedores, asilos y albergues, en donde un gran número de personas pernoctaban y convivían estrechamente. Por tal circunstancia, José María Rodríguez, presidente del Consejo Superior de Salubridad, recomendó que los niños, en particular los jóvenes asilados en estos establecimientos fueran sacados de estos "focos de prostitución" y llevados a ministerios o lugares, en donde se les podía enseñar un oficio..$^{52}$ La función y proyectos de reglamentos de estos asilos tuvieron la intención de que en estos albergues los niños huérfanos no solo fueran aislados y alimentados, sino que recibieran educación y aprendieran un oficio. Tanto los asilos constitucionalistas como el Hospicio de Niños brindaron cobijo, vestido y alimentación, así como educación (instrucción primaria, trabajos de granja y hortaliza). ${ }^{53}$

51 "Lista de asilados mayores de 60 años en el asilo constitucionalista número 4. 29 de noviembre de 1915”. AHSSA, Beneficencia Pública. Establecimientos asistenciales. Asilos Constitucionalistas, leg. 1, exp. 7, f. 1, 2. Desde fines del siglo XVIII en Europa se produjo una transformación en relación con la situación de los niños en el entorno familiar. A partir de entonces los niños fueron separados de los adultos en una "especie de cuarentena, antes de dejarlos sueltos en el mundo". Ariés (2001, p. 12).

${ }^{2}$ Molina del Villar $(2016$, p. 355, 356). Sobre los comedores públicos, véase el estudio de Azpeitia Gómez (2006, p. 275, 276, 279).

53 Guerrero Flores (2008). 
En diciembre de 1915 y en enero de 1916 la curva de mortalidad por tifo en la ciudad de México aumentó de manera abrupta. ${ }^{54}$ En el periódico El Demócrata un articulista atribuía el origen de la enfermedad a las "clases menesterosas, vagabundos nacionales y extranjeros”, por lo que las autoridades debían ejercer "estrecha vigilancia". La nota es interesante debido a que se hablaba de "modernos vagabundos", ya que "expatriados desde su juventud corren de una parte a otra", viviendo a expensas de una "caridad mal entendida". Estas ideas advertían en torno a las condiciones imperantes en los asilos o casas de huérfanos, como podemos observar en la siguiente nota:

Los enfermos de tifo, siempre o casi siempre proceden de esos albergues humildísimos en los que se aglomeran gentes completamente desaseadas y viven en amigable contubernio con toda clase de insectos y cuyos dormitorios, si así pueden llamarse, nadie se cuida de ventilar ni de mantener siquiera en estado de mediana limpieza contribuyendo de este modo a perpetuar la enfermedad y olvidando por completo que la limpieza es la madre de la salud. ${ }^{55}$

Había una fuerte crítica a los asilos que había en la ciudad, considerándolos "antros", pues muchos individuos podían llegar en buenas condiciones de salud y al "cabo de una o dos semanas, enfermaban de tifo, originando un gravísimo peligro para la salubridad pública”. Por tal motivo se conminaba a que las autoridades tuvieran "el deber moral y social de perseguir con mano dura la vagancia y mendicidad, dotando a los asilos donde deben recluirse" de las mejores condiciones higiénicas necesarias "para hacerles agradable su estancia" ${ }^{56}$

En un informe del militar carrancista Pablo González que remitió al mismo Carranza, señalaba que se debía combatir a los mendigos, ya "que las calles se veían plagadas de pequeños mendicantes, sin tutores" ${ }^{57}$ Durante el Porfiriato los mendigos, así como los borrachos y ladrones, fueron objeto de campañas

\footnotetext{
54 Molina del Villar (2016, p. 232).

55 El Demócrata, 13 de diciembre de 1915, p. 3.

56 El Demócrata, 13 de diciembre de 1915, p. 3.

57 Informe de Pablo González que rinde al Primer Jefe Constitucionalista, Venustiano Carranza, documento citado en: Azpeitia Gómez (2006, p. 217).
} 
oficiales para "limpiar a la ciudad".$^{8}$ Aunque menos agresivas, las medidas de reclusión y traslado de enfermos no dejaron de tener tintes de carácter coercitivo. En abril de 1916 un reportero visitó algunos asilos, principalmente el de la Merced, que se ubicaba en la Ribera de San Cosme, en donde antes estaba la Casa de Niños Expósitos. Había un cuantioso número de mendigos y pobres en la ciudad. Tras los grandes esfuerzos emprendidos por el gobierno carrancista, se señalaba que era injustificable toda "clase de mendicidad". Piccato cita una nota de El Universal de 1916, en la que se dejan ver quejas contra los menesterosos por considerarlos agresivos y "que mostraban llagas asquerosas y úlceras, amenazando con infectar a otras personas". ${ }^{5}$

Por tanto, el objetivo fundamental de los asilos constitucionalistas era crear lugares más óptimos o bien mejorar los ya existentes para albergar a los niños huérfanos de la guerra y a los indigentes pobres. Así, en un artículo de El Demócrata, se alabaron las buenas acciones de los constitucionalistas para "regenerar" la vida de estos individuos, señalamiento que nos deja ver el carácter propagandístico del medio. En algunas imágenes, como la que presentamos a continuación, se observan no sólo niños asilados, sino también a las madres mostrando dos momentos: al ingresar al asilo y ya residiendo en dicho establecimiento. El encabezado de la foto y nota se señalaba que en los asilos, hospitales y casas de beneficencia se recibían a todos los que estaban incapacitados para luchar y ganarse la vida. Como ya vimos en la gráfica 1, Hospicio de Niños, en la Casa de Niños Expósitos y en la Escuela Industrial de Huérfanos también se recibieron niños.

No deja de llamar la atención el carácter propagandista de la imagen al mostrar dos recuadros de la madre con los tres niños antes y después de ingresar al asilo. ${ }^{60}$ ¿Cómo eran estos asilos constitucionalistas? ¿Qué tipo de personas estaban recluidas en estos lugares? Los informes, visitas, inspecciones, reglamentos, así como las listas de ingresos y egresos permiten adentrarse en las características y entorno de estos lugares.

\footnotetext{
${ }^{8}$ Piccato (2010, p. 67-69).

59 Piccato (2010, p. 67); Molina del Villar (2016, p. 357, 358).

60 Del Castillo (2009, p. 27, 160).
} 


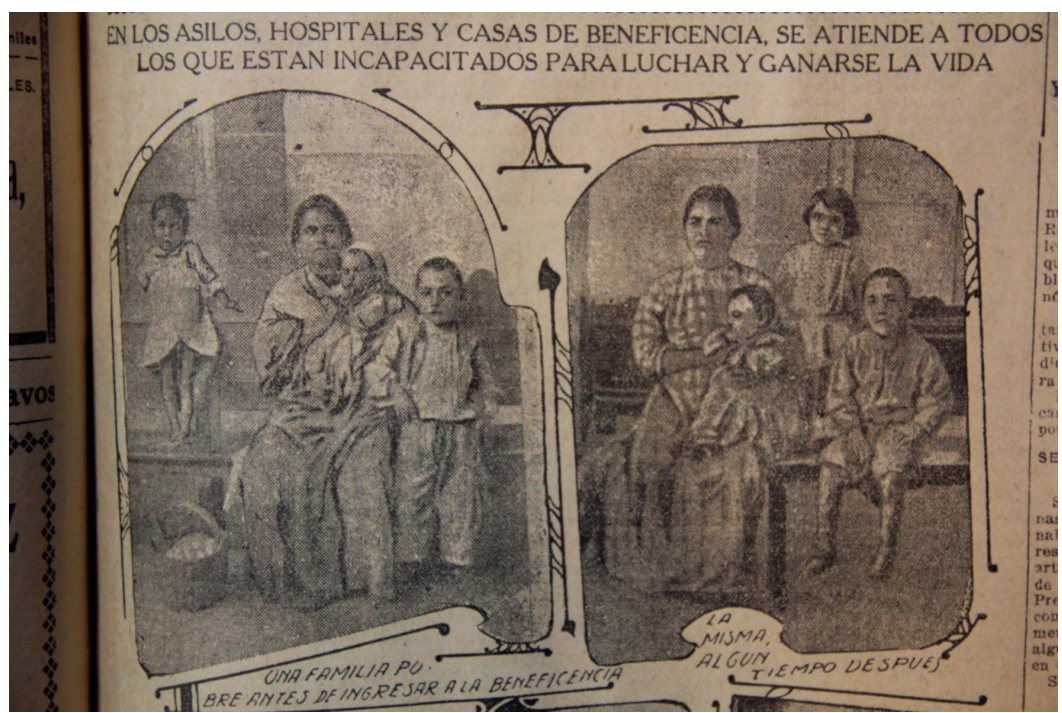

Imagen 1. Asilos constitucionalistas en la Ciudad de México, 1916

Fuente: El Demócrata, 27 de abril de 1916, t. III, n. 505, p. 1.

En 1918 en las estadísticas de ingresos del asilo constitucionalista número 3 aparece una lista de las niñas asiladas con familiares sin especificar cuántos miembros eran. En total aparecen 98 niñas asiladas "que tienen familiares" y que no aclara sí residían o no en dicho establecimiento. ${ }^{61}$ Sin embargo, desde dos años antes en las listas de la población de los asilos y hospitales se incluían los familiares de los empleados que prestaban sus servicios en dichos establecimientos. Lo anterior generó gran controversia entre las autoridades de la Beneficencia. Por ejemplo, en 1916 en los cinco asilos constitucionalistas vivían 41 familiares de los empleados de todas las categorías: directores, administradores, ecónomas, criadas, mozos, cocineras, vigilantes, enfermeras y ayudantes. ${ }^{62}$

61 "Asuntos diversos. Asilados en 1918. Lista de las niñas existentes en esta fecha". AHSSA, Beneficencia Pública, Establecimientos asistenciales, Asilos Constitucionalistas, leg. 4 , exp. 18.

62 "Lista duplicada de los empleados que viven con su familia en los diversos establecimientos de la Beneficencia Pública para descontarles un peso diario por persona. 1916". AHSSA, Beneficencia Pública, Dirección. Dirección General, leg. 21, exp. 12, f. 17. 
El costo de mantener a los familiares de los empleados tuvo un efecto importante a las de por sí menguadas finanzas de La Beneficencia. Así, en agosto de 1916 Carranza ordenó que solo los familiares de los directores podían vivir en estos establecimientos. De inmediato un sinnúmero de solicitudes del resto de los empleados "suplicaron" al primer Jefe Constitucionalista revocar su orden. Empero, se acordó que un plazo de diez días los familiares de los empleados que no tuvieran casa desocuparan sus habitaciones, en caso de tener casa el desalojo sería inmediato. Algunos empleados argumentaron que su casa quedaba lejos de los centros de beneficencia y tardaban mucho tiempo en trasladarse, o bien que bajo su cuidado tenían personas mayores o niños. ${ }^{63}$

En el momento en que Carranza tomó el control de la ciudad en agosto de 1915 se planteó la necesidad de fundar un asilo para los niños huérfanos y las viudas de los soldados muertos en campaña. Este asilo se estableció en el Antiguo Colegio de Mascarones, en Tacuba. En octubre de 1916 la Beneficencia Pública se hizo cargo de un gran número de niños que se encontraban vagando en las calles. Para entonces ya funcionaban tres asilos de menores: la Casa Cuna Constitucionalista que daba cobijo a 500 niños, el Asilo Constitucionalista para niños que brindaba socorro a 400 menores y alimentaba a 200 madres y el Asilo Constitucionalista para Niñas que atendía a 300 huérfanas. ${ }^{64}$

Los asilos constitucionalistas fueron concebidos para internar a los huérfanos de la guerra, aunque no a todas las víctimas de las batallas, pobreza y hambre predominante en aquellos años, en virtud de que solo se daría asilo a los hijos de los militares constitucionalistas. Al respecto, la directora del asilo número 3, Esther P. Vda. de Franco, señalaba que:

He seleccionado entre las niñas asiladas, cuáles deberían quedar, pues no es justo que personas sin méritos de ninguna naturaleza internaran a sus familiares en el establecimiento que son exclusivamente para las pequeñas que han

63 "Circular remitida a los establecimientos para que solo vivan en ellos los directores y los administradores, teniendo que desocupar las habitaciones los otros empleados. Contiene los acuses de recibido y diversas peticiones de los empleados solicitando conservar su vivienda”. AHSSA, Beneficencia Pública, Dirección, Dirección General, leg. 21, exp.11, f. 67.

${ }^{64}$ Azpeitia Gómez (2006, p. 300); Lorenzo Río (2012, p. 195-247); Molina del Villar (2016, p. 358). 
tenido la desgracia de quedar huérfanas, muriendo sus padres en campaña o defendiendo en cualquier forma nuestra querida patria; así que, me cabe la satisfacción, de que la mayor parte de las asiladas, sean hijas de Constitucionalistas. ${ }^{65}$

Para otros directivos el principal objetivo de estos albergues era combatir la mendicidad, ociosidad y vagancia. Así, un informe general de la directora del asilo número 2, Eloísa Vda. de Rivera, enviado a un funcionario de la Secretaría de Gobernación señalaba a propósito de estos asilos que "una de nuestras llagas sociales es la mendicidad que degrada, que prostituye, que envilece”. Por tal circunstancia la directora consideraba importante que las asiladas aprendieran un oficio. ${ }^{66}$

Hagámosle sentir la vergüenza, el santo rubor la dignidad en el rostro del desvalido a quien una extrema desgracia hace tender la mano a la caridad pública. Muchas de estas infelices criaturas están acostumbradas a pedir con naturalidad a chicos y ancianos pedir en la vía pública con quejas lastimeras más o menos sincera o bien justificada, exhibiendo miserias que muchas veces son resultado de vicios crapulosos, e implorando la limosna que les dará el sustento, o quizá la posibilidad de continuar con estos vicios [...] Hagamos que las niñas del asilo adquieran la convicción de lo que significa la adquisición del propio bienestar

65 “Informe que rinde la señora directora del asilo constitucionalista número 2 a la Superioridad, exponiendo las bases en que piensa fundarse para desarrollar su labor en este que le ha sido encomendado. Mixcoac, 8 de marzo de 1916. Firma la directora Esther P. Vda, de Franco". AHSSA, Beneficencia Pública, Establecimientos Asistenciales, Asilos Constitucionalistas, leg. 2, exp. 6, f. 2-4.

${ }^{66}$ Los oficiales de beneficencia en los siglos xix y xx estaban convencidos que los hábitos y la disciplina en el trabajo y productividad servía de base en la construcción de una nueva ciudadanía y de una política moderna. La educación ofrecida en la Casa de Niños Expósitos y en el Hospicio de Niños enfatizaba en el aspecto laboral. Ambos establecimientos frecuentemente dejaban salir niños para aprendices de los artesanos y solían regular adopciones informales de niñas en el servicio doméstico, características que también se perciben en los reglamentos de los asilos constitucionalistas. Blum (2009, p. XVIII). Sobre el trabajo infantil en las décadas de 1930 y 1940, véase Sosenski (2010). 
por el esfuerzo individual y para lograrlo, pongámoslo en condiciones de luchar por la vida y de bastarse por sí mismos. ${ }^{67}$

Una de las funciones de estos asilos constitucionalistas era instruir a las niñas en labores del hogar. ${ }^{68}$ De ahí que la población de la mayoría de ellos fuera femenina. Para los varones se recomendaba hacerlos "buenos obreros": herreros, ebanistas, relojeros, mientras ellas debían aprender a ser "buenas amas de casa”, aptas para "gobernar y dirigir su hogar, qué sepan barrer, coser, planchar, guisar". De acuerdo con la directora, todos estos oficios eran "primorosas labores que los hábiles dedos de muchas mexicanas saben hacer con tanta delicadeza”. Las niñas con más aptitudes podían aprender mecanografía, taquigrafía e incluso inglés. Los reglamentos internos de los asilos regulaban actividades al interior ellos, por lo que presumimos que no sólo interesaba confinar a los niños, sino a que aprendieran un oficio. ${ }^{69}$ A través de la prensa sabemos de muchos niños en situación de calle, lo que preocupó enormemente al gobierno. Durante estos años se llevaron a cabo verdaderas redadas para confinar a los niños a los albergues, hecho que fue desvirtuando los objetivos iniciales que llevaron a fundar estos asilos para dar cobijo a los niños, cuyos padres habían muerto en el campo de batalla.

En las redadas el inspector de policía dictó una disposición ordenando la consignación a las autoridades de todas aquellas personas que no "justificaran tener una ocupación honrada”. De tal suerte que se persiguieron a los desocupados que invadieran las aceras principales de la ciudad, así como aquellos que estuvieran en los billares y demás centros. Se les debía obligar a trabajar y cumplir con sus obligaciones con la sociedad. Esta medida era considerada

67 “Carta de la directora del asilo número 2, Eloísa Vda de Rivera, enviada al señor don Aureliano Esquivel, jefe de la Primera Sección de la Secretaría de Gobernación. 3 de enero de 1917". AHSSA, Beneficencia Pública, Establecimientos Asistenciales, Asilos Constitucionalistas. leg. 2, exp, 7, f. 1-6.

68 Guerrero Flores (2008, p. 66, 67).

69 “Carta de la directora del asilo número 2, Eloísa viuda de Rivera, enviada al señor don Aureliano Esquivel, jefe de la Primera Sección de la Secretaría de Gobernación. 3 de enero de 1917”. AHSSA, Beneficencia Pública, Establecimientos Asistenciales, Asilos Constitucionalista. leg. 2, exp. 7, f. 1-6. 
digna de elogio, pues iba encaminada al "saneamiento del pueblo". ${ }^{70}$ Es interesante observar cómo en la prensa empezaron a ser representados estos niños que vagaban por las calles de la ciudad y que se temía se convirtieran en criminales, hecho que revela las acciones del gobierno por enclaustrar y disciplinar a la gran cantidad de huérfanos y niños abandonados. La imagen 2 de $E l D e-$ mócrata es por demás elocuente, pues aparecen tres fotografías: en el primer recuadro tenemos un grupo de niños solos en la calle, en el círculo de abajo un niño que es golpeado ("zurrando") por un adulto, mostrando que a través de esta vía se lograba disciplinar y, por último, un niño mal vestido y con cara fruncida y enojada, representando al "futuro delincuente". Como señala Del Castillo, las fotografías plasmadas en la prensa tuvieron un creciente peso en la construcción de un imaginario en torno a la niñez y para el caso del periodo analizado en este estudio estas imágenes fueron muy representativas. Las clases bajas fueron consideradas "clases peligrosas”, más proclives a la criminalidad, pues "resultaban todo tipo de individuos "viciosos y carentes de moral”. Algunos autores porfiristas centraron su atención en la infancia, en virtud de que en esta etapa se manifestaban los primeros indicios de la fisonomía criminal. ${ }^{71}$

¿Qué tipo de personal era el que laboraba en estos asilos? En los proyectos de reglamentos de los asilos se describen la función de cada uno de los empleados. A diferencia del periodo porfirista, cuando predominaban los hombres en la dirección de los establecimientos de la Beneficencia ${ }^{72}$, en los asilos constitucionalistas predominaban las mujeres. Algunas de las directoras de los asilos eran viudas, como las que dirigían los asilos número 2 y 3: las señoras Eloísa Viuda de Rivera y Esther Viuda de Franco, respectivamente. Es posible que se trataran de personas de la élite que ofrecieron sus servicios para dirigir estos establecimientos. La directora del asilo número 4 era la señora Herlinda Orive y en 1917 la señora Concepción Gavira se hizo cargo del asilo número 2. Presumimos que estas mujeres eran personas allegadas a la elite carrancista. La propia esposa de Carranza encabezó muchas de las labores benéficas de estos asilos. Por su parte, la Junta de Festejos de la cuarta demarcación de policía realizó

\footnotetext{
70 El Demócrata, 15 de febrero de 1916, p. 1.

${ }^{71}$ Del Castillo (2009, p. 27, 33, 139-258, 178, 179, 187-189).

72 Lorenzo Río (2011a, p. 104-113).
} 


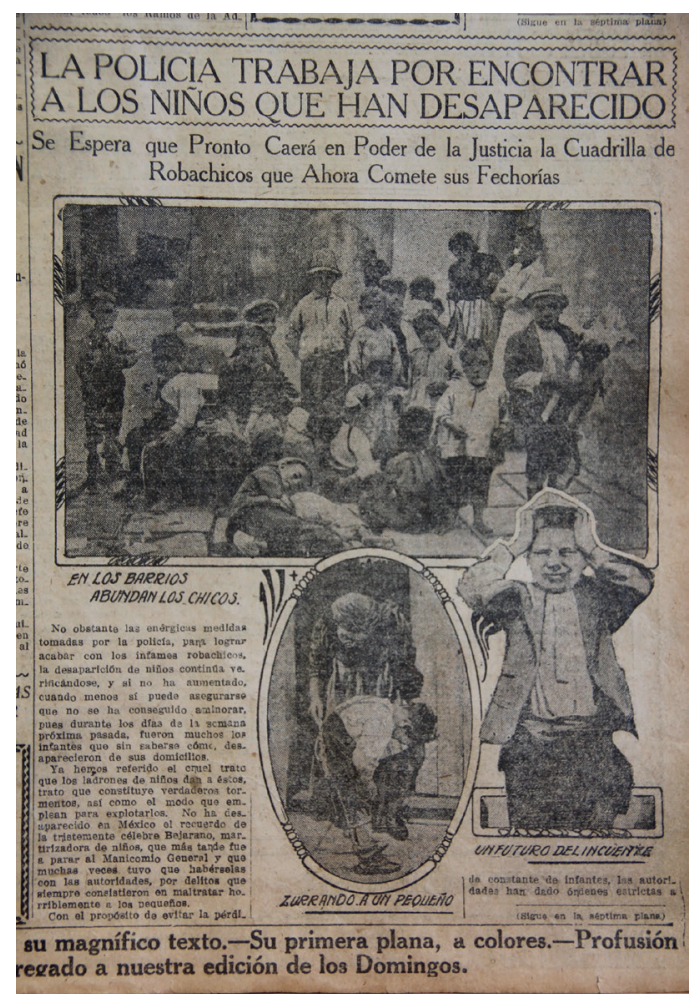

Imagen 2. La prensa reporta gran cantidad de niños huérfanos en la ciudad Fuente: El Demócrata, 22 de marzo de 1916, p. 7.

un acto en el teatro de dicha demarcación en la que se repartió más de 500 prendas de vestir, juguetes y dulces entre los niños pobres. Desde las primeras horas de la mañana un "buen número de niños menesterosos ocuparon la calle de Regina, en donde estaba el teatro, y tal cantidad de niños que era difícil llegar hasta las puertas del teatro". ${ }^{73}$

Un reportero visitó el asilo número 3, ubicado en la calle de la Merced, precisamente en el local que antes era ocupado por la Casa de Niños Expósitos, el cual fue trasladado a las calles de la Ribera de San Cosme. De acuerdo con

73 El Demócrata, 20 de abril de 1916, p. 1. 
dicha visita, el asilo se encontraba en buenas condiciones. El mismo reportero realizó una entrevista al señor Alfredo Duplán, secretario general de la Beneficencia, quien manifestó que en los distintos departamentos de la dependencia había cerca de ocho mil personas asiladas que recibían alimento, vestuario y atención médica. Las dependencias destinadas a asilar a las personas indigentes eran: Casa de Niños Expósitos, los cinco asilos constitucionalistas, Hospicio de Pobres, Escuela Industrial de Huérfanos, Escuela Nacional de Ciegos y Escuela Nacional de Sordomudos. Además, se disponía de hospitales, el General, el Juárez, el Homeopático, el Morelos, un manicomio y el lazareto, así como numerosos consultorios y dispensarios. Según el reportero, los fotograbados e imágenes eran una clara demostración de que eran bien atendidos los indigentes y no se justificaba cualquier clase de mendicidad. ${ }^{74}$

Como vimos en la gráfica 1, las estadísticas de los ingresos y egresos de los niños recluidos en los asilos constitucionalistas revela una población fluctuante, aunque en promedio en cada asilo había entre 200 y 300 internos. Desafortunadamente no en todos los asilos se reportaron las edades de los niños y niñas albergadas, pues solo aparecen listas de nombres con un solo apellido. Sólo el asilo número tres informó sobre las edades de las niñas, las cuales iban a ser trasladadas a asilos de la beneficencia privada que se encargarían de "su cuidado y alimentación”. Se trata de un oficio tardío de 1918, en el que la directora señalaba que muchas de estas niñas habían concluido el cuarto año de primaria. Es interesante mencionar que 103 niñas tenían familia, en tanto 99 era huérfanas y mayores de doce años. Las edades de las niñas con familia eran las siguientes: de cuatro a siete años había once internas; de ocho a doce años eran 78 niñas; y mayores de trece años eran 33. Las menores que debían quedar en el asilo fueron reportadas con las siguientes edades: de cinco a siete años había 21 niñas, de ocho a trece años había 77 niñas. En total se decía que había 269 internas. La lista reporta el nombre y primer apellido de las niñas. Cabe decir que los apellidos variaban, por lo que no podemos distinguir relaciones de parentesco entre los internos. Sólo identificamos cinco parejas de niñas con el mismo apellido y que aparecen registradas juntas, hecho que hace suponer que

74 El Demócrata, 27 de abril de 1916, t III, n. 505, p. 1. 


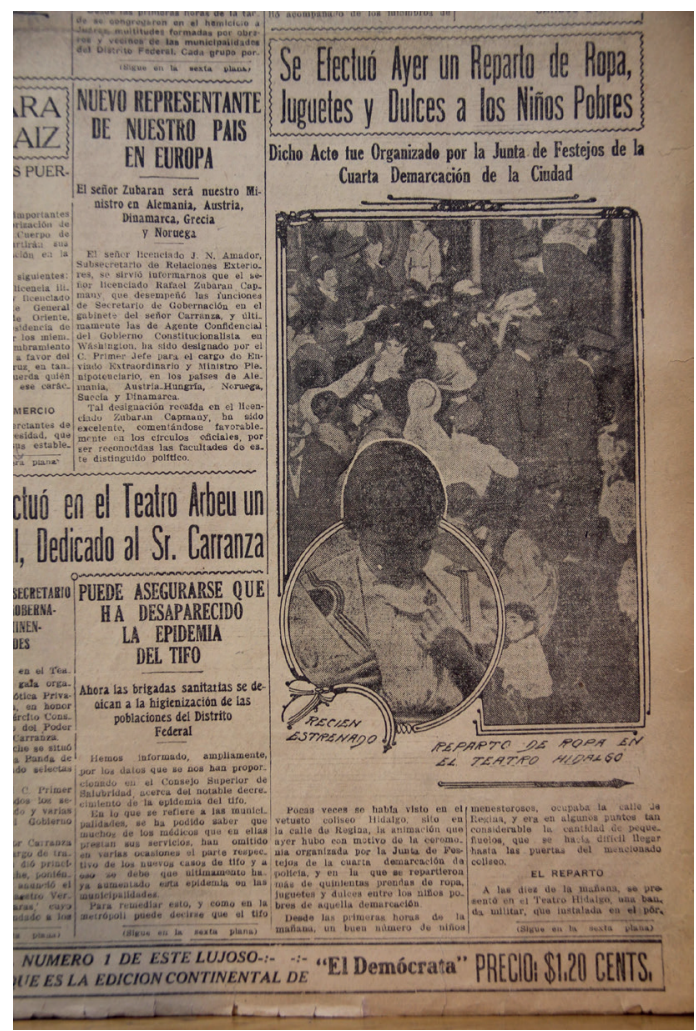

Imagen 3. Reparto de ropa, dulces y juguetes a los niños pobres, 1916

Fuente: El Demócrata, 20 de abril de 1916, p. 1.

eran hermanas. Se tratan de Dolores y Carmen Morales, Lucrecia e Irene Castillo, Loreto y Refugio Velasco, Isaura y Luz González, Catalina y Teresa de Labra. Un año antes, el mismo asilo albergaba 239 niñas distribuidas en siete salones. Solo tres niñas fueron dadas de alta. ${ }^{75}$

Otro asilo con población predominantemente femenina era el número 2, en el que entre febrero y mayo de 1916 el número de internas varió entre 250 y

75 "Cuadro estadístico por edades de las niñas asiladas en el asilo constitucionalista número 3. 13 de mayo de 1918". AHSSA, Beneficencia Pública, Establecimientos Asistenciales, Asilos Constitucionalistas, leg. 4, exp. 18, f. 1, 18; “Lista de niñas existentes el 3 de octubre de 1917”. AHSSA, Beneficencia Pública, Establecimientos Asistenciales, leg. 3, exp. 10. 
352 internos, de los cuales el 5.3\% eran hombres. En febrero había entre tres o cuatro niños hasta que en mayo llegó a la cifra de 19 niños internados. ${ }^{76} \mathrm{~A}$ partir de marzo el número de ingresos aumentó, como se puede observar en la siguiente gráfica.

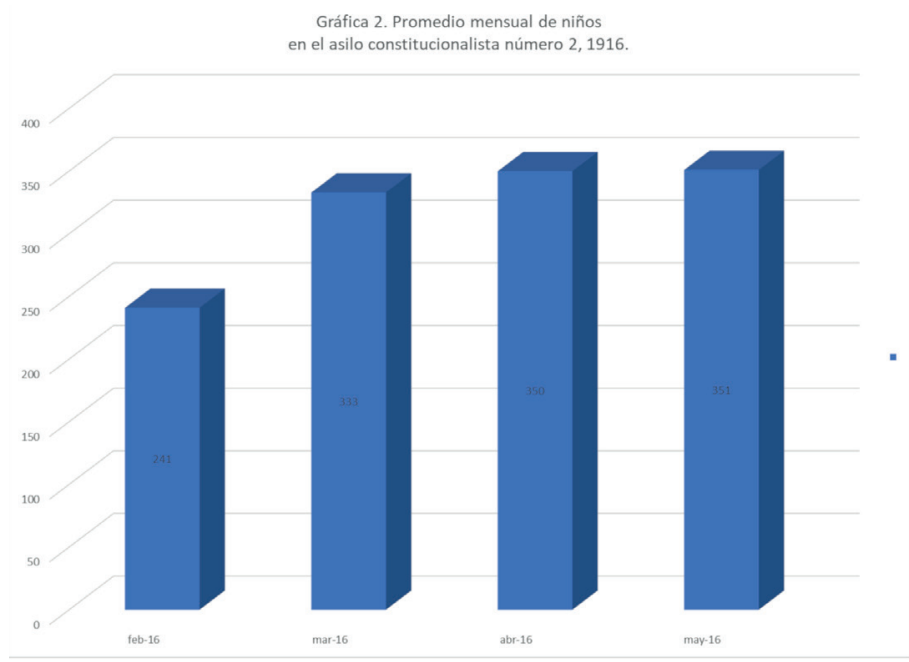

Elaboración propia con base en: "Partes diarias del movimiento de empleados y asiladas del asilo constitucionalista número 2, de enero a mayo de 1916, ubicado en la calle de Donceles 121. La primera lista está firmada el 16 de enero y firma la directora, C. Vda de Rivera". AHSSA, Beneficencia Pública, Establecimientos Asistenciales, Asilos Constitucionalistas, leg. 1, exp. 28 , f. 131.

Quizá el aumento de internos en marzo se debió a un reforzamiento en la política de reclusión de niños, fecha que coincide con los anuncios de la prensa alabando la buena labor de los asilos constitucionalistas y sus excelentes condiciones. Aunque la epidemia de tifo comenzaba ligeramente a disminuir, la campaña sanitaria para combatir la enfermedad todavía estaba a todo vigor. ${ }^{77}$

76 "Partes diarias del movimiento de empleados y asiladas del asilo constitucionalista número 2, de enero a mayo de 1916, ubicado en la calle de Donceles 121. La primera lista está firmada el 16 de enero y firma la directora, C. Vda de Rivera". AHSSA, Beneficencia Pública, Establecimientos Asistenciales, Asilos Constitucionalistas, leg. 1, exp. 28, f. 131.

77 Molina del Villar (2016, p. 321-443). “Dirección general de asilos constitucionalistas. Asuntos diversos de asilados habidos en el establecimiento correspondientes de 1915 a 1916. 
El personal que laboraba en estos asilos constitucionalistas estaba compuesto por los siguientes oficios: la directora, el ecónomo, el administrador y jefe de personal; la prefecta, quien residía y vigilaba el orden, las niñeras, la celadora de la limpieza, médicos y enfermeras. El ecónoma y prefectos representaban los intereses del Estado en los hospicios y escuelas que socorrían a los indigentes y actuaron como enlace entre las autoridades y los desvalidos. En cuanto a la jerarquía administrativa, el director, el prefecto y el ecónomo ocupaban los cargos de mayor relevancia; el resto del personal dependía de ellos. ${ }^{78}$ Sólo hemos encontrados tres proyectos de reglamento, el de los asilos número 2 y 3 . Los dos reglamentos no variaban mucho con respecto a su contenido. El correspondiente al asilo número 3 mostró una redacción más acabada empezando sus primeros artículos con las funciones de la directora, administradora, ecónoma, prefectos, celadoras, niñeras y médicos, finalizando con las obligaciones, derechos y actividades de las asiladas. Por su parte, el asilo número 2 contaba con un primer borrador en el que primero aparecían los artículos dedicados a las actividades de las asiladas: horarios de desayuno, comida y cena, así como higiene, estudio y descanso.79

En tanto en el asilo número 2 se indicaba que solo ingresarían las niñas enviadas por la Dirección General y que estuvieran en condiciones de necesidad. El número 3 especificaba en el capítulo 1, artículo 1 sobre los objetivos del establecimiento de internar a las huérfanas de los soldados revolucionarios muertos en campaña, como señalamos antes y que la propia directora del asilo declaró en un informe. En la reglamentación también se podían admitir a indigentes previa autorización de la Dirección General de la Beneficencia Pública. ${ }^{80}$

Listas de ancianos listos para asilar. 29 de noviembre de 1915". AHSSA, Beneficencia Pública, Establecimientos asistenciales, asilos constitucionalistas, leg. 1, exp. 7, f. 1-3.

${ }^{78}$ Lorenzo Río (2011a, p. 104-113).

79 "Proyecto de reglamento que el asilo número 3 ha adoptado en cuenta de sus necesidades y para el mejor servicio en su régimen interior. 7 de julio de 1915". AHSSA, Beneficencia Pública, Establecimientos asistenciales, Asilos Constitucionalistas, leg. 2, exp. 2, f. 2-8; "Reglamento interior del asilo constitucionalista número 2 correspondientes a 1918". AHSSA, Beneficencia Pública, Establecimientos asistenciales, Asilos constitucionalistas. leg 4, exp. 1.

80 "Reglamento interior del asilo constitucionalista número 2 correspondientes a 1918". AHSSA, Beneficencia Pública, Establecimientos asistenciales, Asilos constitucionalistas. leg 4, exp. 1. 
Las labores de dirección, orden y administración estaban a cargo de la directora, quien también debía dirimir los conflictos laborales. La administradora estaría bajo las órdenes de la directora y tendría bajo su mando la servidumbre del establecimiento. Esta funcionaria llevaría el registro pormenorizado de los alimentos de la Proveeduría, además de pagar los honorarios de los empleados. Los oficios, informes y libros de contabilidad elaborados por estos empleados permiten conocer los asuntos administrativos y la vida al interior de los asilos, así como sus problemas sanitarios y limitaciones presupuestales. La prefecta era otro puesto importante para procurar el orden, aunque también se indicaba que debían cumplir "el papel de una madre cariñosa respecto de sus asiladas". ${ }^{81}$

Las celadoras y niñeras estarían a cargo de los grupos o salas en las que se dividía a la población albergada en los asilos. La celadora con el auxilio de la niñera cuidaría el aseo diario de los dormitorios, aunque las niñas más grandes ayudarían en la limpieza de las camas. Las celadoras registrarían el ingreso y egreso de las niñas, así como velarían por el baño de los niños cada tercer día y los horarios de dormir y levantarse. Las celadoras y niñeras vigilarían el orden en los comedores y la puntualidad en las clases. ${ }^{82}$

Los médicos y enfermeras eran fundamentales en los asilos. Como veremos más adelante, gracias a sus reportes, visitas e inspecciones podemos conocer las condiciones de salud de las internas. El médico debía hacer la visita diaria al establecimiento y reportar a la dirección del asilo y del Consejo Superior de Salubridad cualquier caso de enfermedad infecto-contagiosa. En situaciones de emergencia el médico estaba obligado a acudir al asilo sin importar la hora del día o noche y tenía que extender el certificado de defunción. Por su parte, el

81 "Proyecto de reglamento que el asilo número 3 ha adoptado en cuenta de sus necesidades y para el mejor servicio en su régimen interior. 7 de julio de 1915". AHSSA, Beneficencia Pública, Establecimientos asistenciales, Asilos Constitucionalistas, leg. 2, exp. 2, f. 2-8.

82 "Proyecto de reglamento que el asilo número 3 ha adoptado en cuenta de sus necesidades y para el mejor servicio en su régimen interior. 7 de julio de 1915". AHSSA, Beneficencia Pública, Establecimientos asistenciales, Asilos Constitucionalistas, leg. 2, exp. 2, f. 2-8. 
conserje vigilaría constantemente la portería, anunciando la llegada de algún visitante o familiar. ${ }^{83}$

Las internas también estaban sujetas a una reglamentación específica. Cuando las niñas ingresaban a los asilos debían pasar por el médico, quien evaluaría su estado de salud. La dirección del asilo avisaría a los familiares cualquier accidente que sufriera la interna. Los días de visita eran los domingos, cada quince días. La salida de las niñas estaba sujeta bajo un estricto control, pues sólo podían salir acompañadas de las celadoras; siempre y cuando no se presentara una epidemia. Únicamente se permitía que las asiladas se ausentaran por un periodo máximo de 24 horas, transcurrido este tiempo ya no se permitiría su ingreso. $\mathrm{Al}$ entrar los padres a los asilos debían presentar a la directora una orden de la dirección de la Beneficencia Pública, además de una boleta de identificación. En caso de haber extraviado ésta, se autorizaría su ingreso con el testimonio de "dos personas recomendables y honorables". ${ }^{84}$

El asilo número 3 estableció una normatividad más estricta y cuidadosa para el ingreso de las niñas. De acuerdo con el artículo 2 del reglamento interno, el asilo se dividía en dos clases: preventivo y definitivo. El asilo definitivo significaba que el establecimiento asumía los derechos y obligaciones de tutelaje de los menores de edad y desde ese momento se subrogaba los derechos del tutor legal. Por su parte, el asilo preventivo era cuando se impartía protección urgente e inmediata a una niña que "momentáneamente" se hallare desamparada. En estos casos se notificaría a la dirección de Beneficencia, instancia que determinaría en un plazo de quince días la admisión o salida definitiva de la presunta asilada. Las condiciones eran las siguientes:

La persona que intente la internación de una niña al asilo, deberá comprobar la paternidad y orfandad de la presunta asilada, ya sea con los documentos de estilo del registro civil, o con la declaración de testigos hecha ante la dirección

83 "Proyecto de reglamento que el asilo número 3 ha adoptado en cuenta de sus necesidades y para el mejor servicio en su régimen interior. 7 de julio de 1915”. AHSSA, Beneficencia Pública, Establecimientos asistenciales, Asilos Constitucionalistas, leg. 2, exp. 2, f. 2-8.

84 "Proyecto de reglamento que el asilo número 3 ha adoptado en cuenta de sus necesidades y para el mejor servicio en su régimen interior. 7 de julio de 1915". AHSSA, Beneficencia Pública, Establecimientos asistenciales, Asilos Constitucionalistas, leg. 2, exp. 2, f. 2-8. 
del plantel, y en todo caso, la persona que presente a la niña deberá justificar su honesto modo de vivir y domicilio, para que se pueda exigir la responsabilidad conducente, en caso de que se pretenda una internación atentatoria o hecha contra los derechos de la legítima tutela. ${ }^{85}$

La edad límite de ingreso al asilo era de catorce años y sólo podían residir un máximo de seis años. En este concepto, las niñas de seis y ocho años podían salir al cumplir catorce años. Las de nueve años permanecerían solamente cinco años. Las de diez hasta cuatro años, las de once hasta tres y las de doce hasta dos años, es decir la población en el asilo debía ser menor a los catorce años. ${ }^{86}$ Quizá este límite de edad se encuentra relacionado con el hecho de que a partir de catorce años los niños ya podían ejercer un oficio y completaban su aprendizaje, como señala Sonsenki en su estudio. ${ }^{87}$

Como todo centro de reclusión y aislamiento, la vida al interior del asilo debió ser difícil y restringida por las múltiples reglas que debían cumplir los internos. Me refiero a horarios, visitas estrictas, una alimentación modesta y poco variada. Aunque al parecer algunos asilos sí contaron con buenas instalaciones, en otros empezaron a reportarse problemas de hacinamiento, malas condiciones en el drenaje y alimentación. Las enfermedades de la piel y otras de carácter infeccioso reportadas en las visitas y registros médicos podrían obedecer a estas deplorables condiciones sanitarias.

\section{Condiciones sanitarias en los asilos y enfermedades}

Las precarias condiciones sanitarias de algunos asilos constitucionales revelan otra realidad de muchas notas de la prensa e información oficial. Una muestra

\footnotetext{
85 "Reglamento interior del asilo constitucionalista número 2 correspondientes a 1918". ahssa, Beneficencia Pública, Establecimientos asistenciales, Asilos constitucionalistas. leg 4, exp. 1.

86 "Reglamento interior del asilo constitucionalista número 2 correspondientes a 1918". AHSSA, Beneficencia Pública, Establecimientos asistenciales, Asilos constitucionalistas. leg 4, exp. 1.

${ }^{87}$ En relación al significado e implicaciones sociales y económicas de la edad laboral de los menores, véase Sonsenski (2010, p. 22-24).
} 
son los informes de los directivos, inspecciones de funcionarios y visitas de los médicos que diariamente registraban los padecimientos de los asilados. De las inspecciones más detalladas podemos citar la situación del asilo número 2, el cual en 1916 albergaba cerca de 350 niñas. Al respecto, a principios de 1917 la directora del asilo, señora Eloísa Vda. de Rivera informó al Subsecretario de Gobernación que el asilo carecía de agua, por lo que solicitaba el cambio del inmueble:

Hónrome suplicar a usted con todo respeto; que por carecer en este local de agua no ya suficiente, sino la necesaria para el uso de la alimentación y aseo de las niñas de este asilo, debido a las pésimas condiciones de la instalación de las bombas; así como resultado de los primeros; las condiciones higiénicas del local son terriblemente deficientes por el drenaje, lo cual ha dado ya lugar a quejas del ayuntamiento de esta municipalidad, se digne usted arreglar lo más pronto posible (...) algunos departamentos (...) por ser de necesidad imperiosa para la higiene y demás condiciones de salud de las asiladas. ${ }^{88}$

El desagüe y drenaje estaba en deplorable estado. Las tazas del W. C. no servían, pues carecían de presión de agua. Lo insuficiente de dichos receptáculos, la escasez continua de agua y el mal estado del drenaje representaban una amenaza constante para la salud de las asiladas y de los vecinos. ${ }^{89}$ Cabe referir que el problema del suministro del agua potable a la ciudad había sido un gran problema desde antes de la llegada de Carranza al poder. En las inmediaciones de la ciudad, los grupos contendientes cortaron el suministro de agua. Al parecer, en marzo de 1915 se había restablecido el suministro de agua proveniente de Xochimilco a la ciudad, por lo que había "esperanza de que en la semana

88 “Carta firmada por la directora del asilo constitucionalista número 2, señora Eloísa Vda. de Rivera, fechado el 3 de enero de 1917 y enviado al Subsecretario de Gobernación”. AHSSA, Beneficencia Pública, Establecimientos asistenciales, Asilos Constitucionalistas, leg. 3, exp. 5 , f. 22.

89 "Oficio enviado al director general de Beneficencia Pública firmado el 3 de enero de 1917. Firma el secretario general G. Aragón”. AHSSA, Beneficencia Pública, Establecimientos asistenciales, Asilos Constitucionalistas, leg. 3, exp. 5, f. 22. 
siguiente habría una mejora en el estado sanitario de la ciudad". ${ }^{\circ 0}$ No obstante, la escasez de agua y la insalubridad continuó en la ciudad con la proliferación de brotes de tifo. ${ }^{91}$ Caber referir que la municipalidad de Mixcoac, en donde se encontraba el asilo, fue de las demarcaciones que reportó el número más elevado de cuartos sujetos a desinfecciones durante la campaña sanitaria contra la epidemia de tifo. ${ }^{92}$

La situación se empeoró en el asilo número 2, en virtud de que desde fines de 1916 el inspector sanitario informó que los albañales estaban completamente azolvados. Los excusados tenían una coladera sin obturador por donde salían las materias fecales, estaban "sumamente sucios, debido al azolve" y falta de agua por estar descompuesta la bomba”. El propio presidente municipal de Mixcoac envió una queja y solicitó la visita del inspector sanitario al asilo de niñas. De acuerdo con su informe, los desechos pluviales se acumulaban en el asilo, recorriendo el caño de la calle de Zaragoza por avenida México, 1/a de la Empresa y calle de Ferrocarril, con dirección a la calle Río de la Piedad. El agua sucia y excrementos se estancaba en las calles mencionadas, principalmente en la última provocando un mal olor "que perjudica al vecindario". Se solicitaba una urgente reparación, ya que se temía que de otra manera se "desarrollara una epidemia de tifo", la cual ya se encontraba reinando en la ciudad. La propia directora del asilo se lamentaba de esta situación y pedía se hiciera una excavación para recoger el derrame de materias fecales y se quejaba de la lentitud de las obras debido a que no tenían empleados suficientes para el desazolve, por lo que había quejas constantes de los vecinos. ${ }^{93}$

Los inspectores también identificaron problemas en el asilo constitucionalista número 3. Ahí el principal problema era el equipamiento, pues carecían

90 "Acta número 20, 23 de marzo de 1915". AHDF, Fondo Ayuntamiento, Sección actas de cabildo, n. 281 (enero-julio de 1915).

${ }^{91}$ Molina del Villar (2016, p. 309-311).

92 Molina del Villar (2016, p. 396).

93 "El C. Inspector Sanitario rinde un informe sobre la situación del asilo número 2 de Mixcoac y de la demarcación respectiva. 27 de diciembre de 1916"; "Carta firmada por la directora del asilo constitucionalista número 3, Eloísa Viuda de Rivera, 3 de enero de 1917"; "Carta de la directora del archivo G. Benítez enviada al director General de Beneficencia el 26 de febrero de 1917". AHSSA, Beneficencia Pública, Establecimientos asistenciales, Asilos constitucionalistas, leg. 3, exp 5, f. 22. 
de peroles, vasos, platos, así como de jergas y ropa de dormitorio e interior para las niñas. Solicitaban ropa para 222 asiladas: 100 sábanas, 50 sobre fundas, 250 camisas, 250 calzones, 250 enagüas blancas y 25 toallas. ${ }^{44}$ Por su parte, la directora del asilo Beatriz Viuda de Arres manifestó que en esta semana no se habían bañado ni una sola vez las asiladas, ni se había lavado la ropa, debido a que el jabón era insuficiente y que se había agotado desde el mes de agosto. La directora se lamentaba de que no había conseguido la autorización de un vale por 25 kilos que oportunamente solicitó a la Beneficencia. ${ }^{95}$

En junio de 1917 el director general de la Beneficencia Pública visitó el asilo 3 y encontró que el piso bajo estaba convertido en un basurero, debido a que se encontraban basuras, desperdicios y agua sucia. Además, los excusados por el mismo hecho de carecer de aseo "despiden un mal olor insoportable". Se temía con toda razón el brote de una epidemia ${ }^{96}$ La directora del asilo también se refirió al mal estado de las cañerías de las tazas de baño, las cuales demandaban una pronta reparación. En el lugar constantemente se filtraba agua del piso alto que caía en la planta baja, provocando un mal olor. El personal de limpieza era insuficiente para el barrido y aseo diario de los patios y baños. Antes contaban con dos mozos para la limpieza, pero se ausentaban constantemente debido a lo bajo de los salarios. No se había contratado a nadie más, por lo que la directora solicitó a la Beneficencia general contratar por lo menos a tres personas "percibiendo como único pago la habitación y los alimentos”. De acuerdo con el presupuesto disponible, no se podía contar con más personal de limpieza. ${ }^{97}$

94 “Dirección general. Asilo constitucionalista número 3. Informes de inspectores correspondientes al año fiscal de 1916 y 1917”. AHSSA, Beneficencia Pública, Establecimientos asistenciales, leg.3, exp. 17, f. 3 .

95 “Informe de la inspectora enviado al C. Subdirector de la Beneficencia Pública. La firma (rúbrica) Cortés Vda. De Bailleres. México, 20 de mayo de 1917”. AHsSA, Beneficencia Pública Establecimientos asistenciales, Asilos constitucionalistas, leg. 3, exp. 5, f. 3.

96 “Informe de visita al C. director General de la Beneficencia Pública. Rúbrica del inspector Paucherdo Ruíz. 27 de julio de 1917”. AHSSA, Beneficencia Pública, Establecimientos asistenciales, Asilos Constitucionalistas, leg. 3, exp. 17, f. 6, 7.

97 “Oficio en respuesta fechada el 4 de agosto de 1917 por la directora Concepción Gavira, dirigida al director general de la Beneficencia Pública”. AHSSA, Beneficencia Pública Establecimientos asistenciales, Asilos constitucionalistas, leg. 3, exp. 17, f. 8-8vta. 
Cabe referir que precisamente en este asilo se llevó a cabo un registro pormenorizado de las enfermedades de las asiladas. En las siguientes gráficas observamos una gran cantidad de niñas con problemas de la piel: sarna, excema y tiña, padecimientos que podrían ser consecuencia de falta de higiene y una deficiente alimentación. La "enfermedad de los ojos" podría tratarse de conjuntivitis, asociado también a malos hábitos higiénicos. En relación con el tifo exantemático y otras enfermedades infecciosas, sabemos que entre octubre de 1915 y septiembre de 1916 un total de 129 niños de los asilos, casas de huérfanos y escuelas fueron trasladados a los distintos hospitales de la ciudad de México.

Como se aprecia, el asilo número 3 fue el que reportó más problemas de salud, situación relacionada con las pésimas condiciones de higiene referida páginas atrás. La precaria situación higiénica y la proliferación de diversas enfermedades infecciosas no fue exclusivo de estos asilos, ya que en los otros albergues y hospicios se registraron enfermedades respiratorias, gastrointestinales, fisiológicas. El gobierno no se dio abasto para sostener el gran número de niños internados en estos años críticos. ${ }^{98}$

Otro problema en los asilos fue la calidad de los alimentos. Por ejemplo, en el asilo número 2 la directora solicitaba a la Proveeduría que el reparto de carne fuera más equitativo, en virtud de que las raciones destinadas al asilo consistían sólo en costillares que no bastaban para la alimentación de las asilada por tener mayor cantidad de hueso que de carne. ${ }^{99}$ Gracias a la gestión de la señora directora, se habían logrado almacenar semillas y ya no requería más cantidades, en virtud de que alcanzaba hasta julio de 1916. Empero, se quejaba de que el precio por litro de la leche había subido a 1.50 pesos, por lo que pedía

${ }^{98}$ Al respecto, Guerrero Flores (2008, p. 69) refiere un aumento importante de niños que ingresaron en la Casa de Niños Expósitos entre 1913 y 1920, muchos de los cuales fallecieron por diversas causas. En 1916 ingresaron 592 internos, de los cuales murieron 258. Aunque el autor no refiere las causas, probablemente estos decesos fueron a consecuencia de las epidemias de tifo y viruela que en aquellos años estaban provocando graves estragos en la población.

99 Dirección general. Asilo constitucionalista número 2. Asuntos diversos de alimentación correspondiente al año fiscal 1915 y 1916". Oficio firmado el 26 de mayo de 1916 y enviado al director general de la Beneficencia Pública y firmada por la directora E. C. Vda. de Rivera. AHSSA, Beneficencia Pública, Establecimientos asistenciales, Asilos constitucionalistas, leg. 2, exp. 17, f. 1-3.

ESTUDIOS DE HISTORIA MODERNA Y CONTEMPORÁNEA DE MÉXICO 55, enero-junio 2018, 195-242

DOI: http://dx.doi.org/10.22201/iih.24485004e.2018.55.64521 


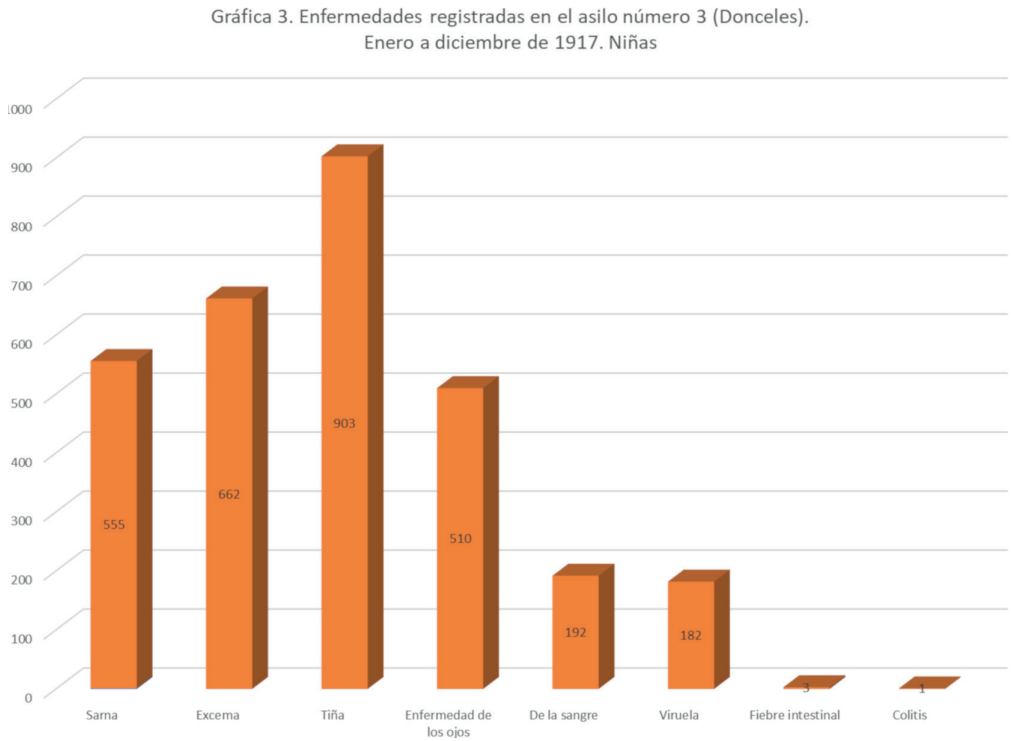

Elaboración propia con base en: "Informe del médico del asilo número 3, enero a diciembre de 1917". AHSSA, Beneficencia Pública, Establecimientos asistenciales, Asilos constitucionalistas, leg. 3, exp. 4, f. 52.

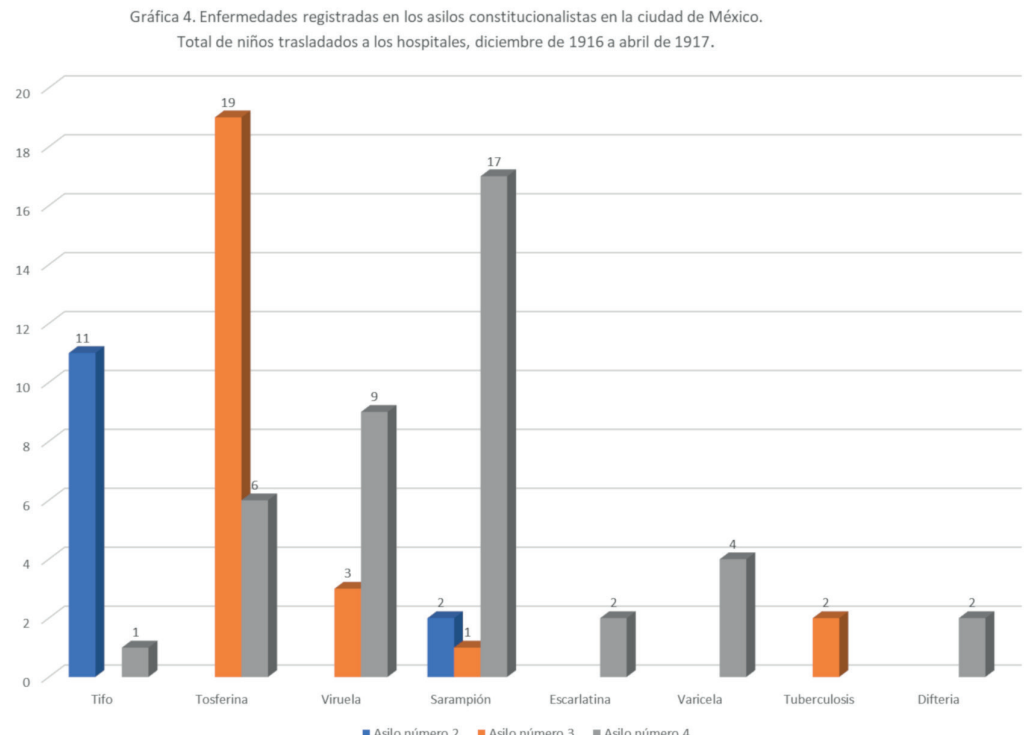

Elaboración propia a partir de "Libro de traslados de enfermos infecto-contagiosos. Contiene nombres, enfermedades, domicilios, procedencia, destinos, observaciones, la mayor incidencia es de tifo, octubre de 1915 a octubre de 1916". AHSSA, Salubridad Pública. Epidemiología, caja 11, exps. 1 y 2. 
autorización para cubrir la diferencia. La cantidad solicitada para satisfacer las necesidades del asilo del mes de julio ascendía a \$3 100. Finalmente se autorizaron $\$ 6$ ooo para cubrir el mes de septiembre. ${ }^{100}$

No sabemos a ciencia cierta sí la calidad y cantidad de alimentos era óptima y suficiente para una buena nutrición de las niñas internas. Lo que sí observamos es que no era muy variada, ya que consistía en carne, pan y leche. Para el asilo número 2, ubicado en Donceles, podemos calcular el consumo per cápita. De acuerdo a un reporte de marzo de 1916, el asilo contaba con 42 empleados, ocho familiares de los empleados y un total de 349 asiladas. El consumo diario de pan era de alrededor de 1 ooo o 1800 piezas de pan; la cantidad de carne no variaba mucho, ya que diariamente se consumía 40 kilos de carne, aunque a partir de febrero de 1916 al crecer el número de asilados aumentó el consumo a 65 kilos de carne; la cantidad de leche casi fue la misma de 80 y 100 litros. ${ }^{101}$ Entonces, sí dividimos estas cantidades en gramos y mililitros tenemos que cada niña recibía al día 114 gramos de carne, o sea una porción aceptable de carne, 2.8 piezas de pan y 286.5 mililitros de leche. Dependiendo el peso y edad del individuo, se requiere 50 o 60 gramos de proteína al día. Es decir, la dieta de las asiladas podía contener una cantidad suficiente de proteína animal proveniente de la carne de res y leche, así como de carbohidratos por las dos porciones de pan que recibían al día. No obstante, la dieta no era muy variada y no se reportan otro tipo de alimentos, como el consumo de verduras y legumbres. En contraste, algunos comedores públicos como el número 8 de Tacubaya reportaron una comida más balanceada compuesta por carne, frijoles, arroz y garbanzos. ${ }^{102}$ No debemos olvidar los años precedentes cuando muchas familias padecieron hambre, debido a la propia carestía provocada por la confrontación

100 “Asuntos diversos de alimentación correspondientes al año fiscal 1916 y 1917. Dirección general. Asilo constitucionalista número 2". AHSSA, Beneficencia Pública, Establecimientos asistenciales, Asilos constitucionalistas, leg. 2, exp. 25, 15 fojas.

101 "Partes diarias del movimiento de empleados y asiladas del asilo constitucionalista número 2, de enero a mayo de 1916, ubicado en la calle de Donceles 121. La primera lista está firmada el 16 de enero y firma la directora, C. Vda de Rivera”. AHSSA, Beneficencia pública, Establecimientos asistenciales, Asilos constitucionalistas, leg. 2, exp. 28, f. 131.

102 "Relación de niños y niñas que acudieron a los comedores públicos. 31 de diciembre de 1915". AHSSA, Beneficencia pública, Establecimientos asistenciales, Asilos constitucionalistas, leg. 2, exp. 23, f. 4-7. 
de las fuerzas contendientes que incendiaron rutas del ferrocarril, interrumpiendo el abasto de alimentos a la ciudad. ${ }^{103}$ Así que disponer de un plato de comida al día en estos asilos y puestos de socorro podría considerarse todo un manjar.

La alimentación de los asilos fue empeorando con el tiempo. Por ejemplo, los reportes del mismo asilo en 1917 señalan que la carne estaba en mal estado. La directora, Concepción Gavira, remitió el siguiente oficio:

Con mucha frecuencia, la carne que remite la Proveeduría general de esa beneficencia [...] viene en completo estado de descomposición. Como tal cosa redunda en perjuicio de las asiladas de este propio establecimiento, pues tirando dicha carne y supliéndolas con cualquier otra cosa, como varias veces se ha hecho, se les priva del único alimento nutritivo que tienen y dándoselas aunque sea ligeramente descompuesta se les expone a la serias enfermedades de estómago que frecuentemente se están registrando, [...] temo fundadamente que de seguir así, se desarrolle una epidemia en este asilo. ${ }^{104}$

Podemos presumir que el presupuesto asignado a los asilos disminuyó y dejó de ser un asunto de prioridad para el gobierno constitucionalista. Indagar en los factores que llevaron al cierre definitivo de estos asilos a fines de 1918 es asunto de interés para una investigación de mayor aliento, pero por ahora podemos conjeturar algunas causas en las conclusiones.

\section{Reflexiones finales}

A mediados de 1918 el gobierno dispuso el cierre de los asilos constitucionalistas 2, 3 y 4, remitiendo a más de 800 menores al Hospicio de Niños. ${ }^{105}$ Por ejemplo, en el número 3 se solicitaba que 20 niñas fueran trasladadas al asilo del Carmen

${ }^{103}$ Sobre el hambre en la ciudad durante estos años, comedores públicos y puestos de socorro, véase Azpeitia Gómez (2006).

104 "Carta firmada por la directora Concepción Gavira y enviada a la Dirección General de la Beneficencia Pública, 4 de agosto de 1917”. AHSSA, Beneficencia Pública, Establecimientos asistenciales, Asilos constitucionalistas, leg. 3, exp. 18, f. 4.

105 Guerrero Flores (2008, p. 70). 
y diez al asilo de mendigos. Otras cinco niñas en calidad de expósitas también fueron remitidas al asilo del Carmen que dependía de la beneficencia privada. ${ }^{106}$ A mediados de este año en ese mismo asilo fueron devueltas a sus familiares 103 niñas, ya que se estaba observando que muchas de ellas no estaban del todo desamparadas ni en completo abandono:

Hemos recibido órdenes terminantes del C. Gobernador del D.F a fin de que sean devueltas a sus familias 103 asiladas de este establecimiento conforme a la lista adjunta [...] En tal virtud se servirá usted mandar llamar con el carácter de urgente a los familiares y hacerles respectivamente la entrega de las niñas, indicándoles con toda claridad qué (...) la beneficencia pública solo debe impartir protección a las personas absolutamente necesitadas $[\ldots]^{107}$

En el oficio se indicaba que los familiares de estas niñas no estaban en total pobreza y no había necesidad de que permanecieran asiladas. Aparecen tres listas con los nombres de las niñas que tenían familia. En la primera con fecha de enero de 1918 se registraron 269 niñas, 98 en una segunda lista sin fecha y 195 en mayo de 1918. ${ }^{108}$ Podemos conjeturar que la salida de estas niñas obedecía al hecho de que el propio asilo ya no se daba abasto para atender la población, además de que en el caso particular de este albergue identificamos problemas sanitarios y presupuestales. Queda por indagar qué pasó con la población internada en el resto de los asilos constitucionalistas, así como en los demás hospicios y asilos existentes en la ciudad. Sabemos de la fundación de un sexto asilo constitucionalista para ancianos, población desvalida y también vulnerable

106 "Oficio dirigido al subdirector de la Beneficencia Pública y firma del oficial mayor Manuel Sotomayor. 7 de marzo de 1918”. AHSSA, Beneficencia pública, Establecimientos asistenciales, Asilos constitucionalistas, leg. 4, exp. 18, $19 \mathrm{f}$.

107 "Oficio firmado por el subdirector y prosecretario, el cual fue remitido a la señora directora del asilo número 3. 11 de junio de 1918”. AHSSA, Beneficencia pública, Establecimientos asistenciales, Asilos constitucionalistas, leg. 4, exp. 18, f. 23.

108 "Oficio con sello de urgente firmado por el secretario general y dirigido al C. Subdirector de Beneficencia Pública. 12 de junio de 1918”. AHSSA, Beneficencia pública, Establecimientos asistenciales, Asilos constitucionalistas, leg. 4, exp. 18, f. 27. 
en estos tiempos de guerra. Nos referimos al asilo ubicado en Popotla, cuyo edificio estaba destinado a albergar a los niños. ${ }^{109}$

La idea original de asilar solo a los niños huérfanos de generales carrancistas fue cambiando, pues al final pudimos observar que llegaron muchos niños y niñas cuyos padres no podían mantenerlos. Lugares de reclusión, de atención emergente y la idea de formar niños con un oficio fueron de los objetivos de esta gran campaña sanitaria y de beneficencia del gobierno carrancista. La vida de estos asilos concluyó en 1918, cuyas causales de cierre podemos atribuir a problemas sanitarios, presupuestales y a que se crearon precisamente por ser albergues temporales, surgidos en unos años críticos para la capital del país.

\section{Fuentes}

Archivos

Fondo Ayuntamiento, Sección actas de cabildo (AHDF)

Beneficencia Pública, Dirección, Dirección General (AHSSA)

Beneficencia Pública, Establecimientos Asistenciales, Asilos Constitucionalistas (AHSSA)

Dirección, Dirección General (AHSSA)

Salubridad Pública, Epidemiología (AHSSA)

Bibliografía

(1918). Censo de Población de Estados Unidos Mexicanos. t. 1. México: Oficina Impresora de la Secretaría de Hacienda.

Agostoni, C. (coord.). (2008). Curar, sanar y educar. Enfermedad y sociedad en México, siglos XIX y XX. México: Universidad Nacional Autónoma de México/Benemérita Universidad Autónoma de Puebla.

109 "Carta firmada por el director general y enviada a Alfonso Alpuche, jefe del departamento de confiscaciones y bienes intervenidos. Fecha el 5 de abril de 1916". AHSSA, Beneficencia Pública, Establecimientos asistenciales, Asilos Constitucionalistas, leg. 3, exp. 8, f. 3. 
Alanís, M. (2016). La atención médica infantil en la ciudad de México. Discursos, imaginarios e instituciones, 1861-1943. México: Universidad Autónoma del Estado de Hidalgo.

Alcubierre Moya, B. y T. Carreño King (1997). Los niños villistas. Una mirada a la historia de la infancia en México, 1900-1920. México: Instituto Nacional de Estudios Históricos de la Revolución Mexicana, Secretaría de Gobernación.

Aréchiga Córdoba, E. (2007). “Educación, propaganda o ‘dictadura sanitaria'. Estrategias discursivas de higiene y salubridad públicas en el México posrevolucionario, 1917-1945”. Estudios de Historia Moderna y Contemporánea 33, p. 58-88.

ARIÉs, P. (2001). El niño y la vida familiar en el Antiguo Régimen. México: Taurus.

Arrom, S. M. (2011). Para contener al pueblo: el Hospicio de Pobres de la ciudad de México (1774-1871). México: Publicaciones de la Casa Chata.

Ávila Espinosa, F. A. (1991). "La ciudad de México ante la ocupación de las fuerzas villistas y zapatistas. Diciembre de 1914-junio de 1915”. Estudios de Historia Moderna y Contemporánea de México 14, documento 183 (p. 1-17) (Artículo disponible en http://www.historicas.unam.mx/moderna/ ehcm14/183.html).

Azpeitia Gómez, H. (2006). El cerco militar a la ciudad de México en 1915. Hambre y revolución. México: Centro de Investigaciones y Estudios Superiores en Antropología Social. (Trabajo inédito).

BARbosa, M. (2011). "La atención de los pobres durante la década revolucionaria”, en Patrimonio de la Beneficencia Pública. 150 años de asistencia social, México, p. 186-219. México: Patrimonio de la Beneficencia Pública.

Barbosa, M. (2012). "La política en la ciudad de México en tiempos de cambio (1903-1929)”, en A. Rodríguez Kuri (coord.). Historia política de la Ciudad de México (desde su fundación hasta el año 200o), p. 363-408. México: El Colegio de México.

Buum, A. S. (2009). Domestic Economies. Family, Work and Welfare in Mexico City, 1884-1943. Estados Unidos: University of Nebraska Press/Lincoln and London. 
Carrillo, A. M. (1999). "El Servicio de Higiene Escolar en México: Congreso Higiénico Pedagógico de 1882”. Revista Mexicana de Pediatría 66 (n. 2), p. 71-74.

Carrillo, A. M. (2005). "Vigilancia y control del cuerpo de los niños. La inspección médica escolar (1896-1913)”, en L. Cházaro y R. Estrada (eds.). En el umbral de los cuerpos. Estudios de antropología e historia, p. 171-207. Guadalajara: El Colegio de Michoacán/Benemérita Universidad Autónoma de Puebla.

Del Castillo, A. (2009). Conceptos, imágenes y representaciones de la niñez en la Ciudad de México, 1880-1920. México: El Colegio de México/Instituto Mora.

Fregoso Centeno, A. (2009). "Infancia y maternidad después de la Revolución: sus imágenes y representaciones a través de un diario tapatío (1917-1943)”. Comunicación y Sociedad. Departamento de Estudios de la Comunicación Social (1917-1943), n. 11, p. 163-192.

González Navarro, M. (1974). Población y Sociedad en México (1900-1970). México: Universidad Nacional Autónoma de México.

Greer Gordon, R. (1966). The Demographic Impact of Revolution, 1910-1921. Texas: University Texas.

Guerrero Flores, D. (2007). "La valoración del trabajo infantil en México (19101920)", en A. Mayer (coord.). México en tres momentos: 1810-1910-2010. p. 121-147. México: Universidad Nacional Autónoma de México, Instituto de Investigaciones Históricas.

Guerrero Flores, D. (2008). "Los niños de la Beneficencia Pública en la ciudad de México, (1910-1920)”, en D. Salazar Anaya y M. E. Sánchez Calleja. Niños y adolescentes: normas y transgresiones en México, siglos XVIII-XX, p. 61-84. México: Instituto Nacional de Antropología e Historia.

Hernández Bringas, H. H. (2001). La mortalidad infantil en México durante los años de la crisis. México: Universidad Nacional Autónoma de México, Centro Regional de Investigaciones Multidisciplinarias.

LoRenzo Río, M. D. (2011a). El Estado como benefactor. Los pobres y la asistencia pública en la ciudad de México, 1877-1905. México: El Colegio de México/El Colegio Mexiquense. 
Lorenzo Río, M. D. (2011b). “Avatares por una administración eficiente en la República Restaurada”, en Patrimonio de la Beneficencia Pública. 150 años de asistencia social, p. 112-147. México: Patrimonio de la Beneficencia Pública.

Lorenzo Río, M. D. (2012). "Los indigentes ante la asistencia pública. Una estrategia para sobrevivir en la ciudad de México, 1877-1905”. Historia Mexicana LXII (n. 1), p. 195-247.

Marten, J. (1998). The Children's Civil War. (Civil War America). Chapel Hill: University of Noth Carolina Press.

Marten, J. (ed.) (2012). Children and Youth during Civil War (Children and Youth in America). Estados Unidos, Nueva York: University Press.

MEYer, E. (2000). “¿Dónde están los niños? Reflexiones para una historia de la infancia durante la Revolución”, en L. Espejel López (coord.). Estudios sobre el zapatismo. p. 439-459. México: Instituto Nacional de Antropología e Historia.

Ordorika, M. y J. L. Lezama (1993). "Consecuencias demográficas de la Revolución mexicana”, en A. Arenzana (ed). La población de México. v. 4, p. 8-31. México: Consejo Nacional de Población.

Molina del Villar, A. (2016). Guerra, tifo y cerco sanitario en la ciudad de México, 1911-1917. México: Publicaciones de la Casa Chata.

Piccato, P. (2010). Ciudad de sospechosos: crimen en la ciudad de México, 190o-1931, México: Publicaciones de la Casa Chata.

Rodríguez KuRI, A. (1996). La experiencia olvidada. El ayuntamiento de México: política y gobierno, 1876-1912. México: El Colegio de México/Universidad Autónoma Metropolitana Azcapotzalco.

Rodríguez Kuri, A. (2010). Historia del desasosiego. La revolución en la ciudad de México, 1911-1922. México: El Colegio de México.

Sosenski, S. (2010). Niños en acción en la ciudad de México, 1920-1934. México: El Colegio de México.

UlloA, B. (2000) "La lucha armada (1911-1920)", en Historia General de México. p. 759-821. México: El Colegio de México. 